\title{
Sediments vs. Historical narratives: The use of soil magnetic properties to evaluate the existence of a historical fire in an 18th century Spanish fort (Patagonia, Argentina)
}

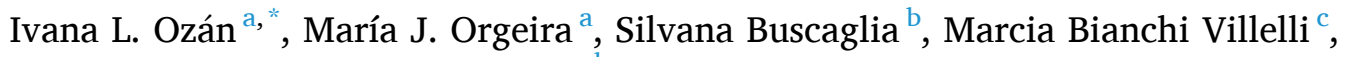 \\ Carlos A. Vásquez ${ }^{a}$, Ariel Cieplicki ${ }^{\mathrm{d}}$, Matías Naselli ${ }^{\mathrm{a}}$ \\ ${ }^{a}$ Consejo Nacional de Investigaciones Científicas y Técnicas (CONICET) - Universidad de Buenos Aires (UBA). Instituto de Geociencias Básicas, Aplicadas y Ambientales \\ de Buenos Aires, Intendente Güiraldes 2160, C1428EHA Buenos Aires, Argentina \\ ${ }^{\mathrm{b}}$ CONICET - Instituto Multidisciplinario de Historia y Ciencias Humanas, Saavedra 15, 1083ACA Buenos Aires, Argentina \\ ${ }^{\mathrm{c}}$ CONICET - Instituto de Investigaciones en Diversidad Cultural y Procesos de Cambio -Universidad Nacional de Río Negro, Bartolomé Mitre 630, R8400AHN San Carlos \\ de Bariloche, Argentina \\ ${ }^{\mathrm{d}}$ Facultad de Ciencias Exactas y Naturales - UBA. Intendente Güiraldes 2160, C1428EHA Buenos Aires, Argentina
}

\section{A R T I C L E I N F O}

\section{Keywords:}

Superparamagnetic grains

Thermomagnetic curves

Experimental heating

Adobe-wall foundation

Semi-arid environments

\begin{abstract}
A B S T R A C T
The present work aims to evaluate if sediments from the Spanish fort Fuerte San José (1779-1810 CE) located in Península Valdés, Province of Chubut, Argentina, show signs that could be attributed to the documented fire caused by native populations in $1810 \mathrm{CE}$. Three different magnetic signatures indicative of thermoalteration were assessed in raw and experimental heated samples: the presence of superparamagnetic minerals, the existence of reversibility on thermomagnetic curves and further relative changes concerning ferri-, anti-ferro- and paramagnetic minerals. Results show that only samples corresponding to an adobe-wall foundation recorded magnetic changes caused by thermoalteration processes, below $400{ }^{\circ} \mathrm{C}$, likely related to the historical fire. Relatively higher organic matter values contained in the adobe-walls, thatched roofs and/or any combustible content placed inside the structure could have been the factors which promoted such magnetic thermoalterations circumscribed to only one sector of the site. A low-magnitude fire may also explain the lack of a magnetic-soil thermoalteration in other sectors of the Fuerte San José. Thus, data do not support a massive fire, as narratives repeated by historians described. The methodological design presented here could be a fruitful approach to discuss natural or anthropogenic paleo-fires in arid/ semi-arid environments.
\end{abstract}

\section{Introduction}

The Spanish colonization of the Patagonian Atlantic coast took place in the late 18th century, in the context of Bourbon reforms and a persistent crisis with the British Empire. Particularly in Península Valdés (Patagonia Argentina; Fig. 1), the Spanish settled two enclaves in 1779: the Fuerte San José, a fortification located in the southeast corner of the homonymous gulf, and the Puesto de la Fuente, a complementary productive settlement near Salina Grande (Fig. 1). Both settlements lasted 31 years, under conditions of extreme isolation, shortage, precariousness and inter-ethnic conflicts. In 1810, they were supposedly destroyed by an indigenous attack (Buscaglia and Bianchi Villelli, 2016; Bianchi Villelli, 2017; Buscaglia, 2017).
For decades historians stressed that the Fuerte San José was destroyed by a massive fire caused by native populations, arguing their "irrational and violent" character in nature. However, data from documentary and archaeological has questioned this version. In this context, the aim of this work is to evaluate the existence and magnitude of the documented fire at the Fuerte San José by the study of soil magnetic properties. At this regard, some preservational expectations for an openair fire at the Fuerte San José are presented, in order to identify places to find three different magnetic signatures of thermoalteration: the presence of superparamagnetic (SP) minerals, the existence of reversibility of thermomagnetic curves and other relative changes concerning ferri-, anti-ferro and paramagnetic minerals.

\footnotetext{
* Corresponding author.

E-mail addresses: iozan@gl.fcen.uba.ar, ivanalozan@gmail.com (I.L. Ozán).
} 


\subsection{Regional setting}

The Fuerte San José site is located in an island-like peninsula (Baldi et al., 2017) of the southeastern extra-andean Patagonian region (Fig. 1). The geomorphologic setting of the study area corresponds to the Coastal Piedmont Pediment Unit. It comprises old fluvial terraces and stabilized and superimposed active dunefields dissected by Holocene stream (Bouza et al., 2017a; Fig. 2A, B). The archaeological site under study is on aeolian deposits from those active and vegetated dunefields mostly composed by quartz, plagioclase, K-feldespar, plutonic and volcanic rock fragments and minor proportions of opaque minerals, carbonates, pyroxene, amphibole, glauconite and chlorite (Bouza et al., 2017a).

Cold and arid-semiarid conditions characterized the area, with a mean annual temperature of $\sim 13^{\circ} \mathrm{C}$, an annual average precipitation of $\sim 230 \mathrm{~mm}$ and relatively intense southwestern winds (Coronato et al., 2017 and references therein). Though wildfires in the region are frequent, the location of the Fuerte San José is in a "very low risk" area (Blanco et al., 2017), with no record of fire in the last decades. These climatic conditions define shrub-perennial grass steppes, classified within the Patagonian Phytogeographical Province (León et al., 1998). The sparse vegetation that leaves large patches of bare soils sets favorable conditions for wind erosion, raindrop impact, laminar runoff, flow erosion and the formation of deep gullies (Haller et al., 2001; Bouza et al., 2017b; Coronato et al., 2017). This highly dynamic geomorphology coupled with arid conditions, define very poor-developed alkaline soils (pH 7.6-9.9) (Bouza et al., 2017a, 2017b).

\subsection{The Fuerte San José: The historical and archaeological setting}

The Fuerte San José comprises a complex case study regarding its spatial organization, functionality and architecture, due to scarce and fragmentary documentary and archaeological data caused by the perishable and precarious building materials used during the thirty-one years of colonial occupation, successive re-occupation episodes after its abandonment and subsequent vandalism. Only a single report describes the population core of the settlement, which was located between two hills and comprised a closed "plaza" with a food store, barracks, two rooms and a chapel (Soler and García, 1779). Though the specific location of the latter is not provided, settlers vaguely mentioned in 1782 the use of reed (Saccharum sp.) for its construction (Martínez, 1782). However, leather roofs are reported as well for 1789 (Pérez, 1796b). Documents indicate that the chapel roof is destroyed by a hurricane in 1796 , but is subsequently re-built with original materials and wood in another place sheltered from the winds (Pérez, 1796b).

Outside the population core, two hospitals, kitchens and a small fort over a hill surrounded by a ditch are mentioned, together with a gunpowder warehouse and a cemetery lacking in spatial references (Viedma, 1779). In addition, the presence of a wooden palisade around the population core (Bordas, 1793) and the building of new warehouses and a bakery with an oven is also described (Pérez, 1796a). Willow wood, leather, straw, and subordinate adobe (i.e., sun-dried mud brick containing straw as stabilizer; Vega et al., 2011), bricks and tiles are the main reported construction materials, supplied from the Fuerte Nuestra Señora del Carmen -about $300 \mathrm{~km}$ to the north- to build palisades, walls and roofs of the Fuerte San José (Fig. 3A).

As a result of conflicting relations with indigenous populations, the Spanish settlement is attacked in 1810 . Testimony of survivors indicates that indigenous burnt the artillery, gunpowder, weapons and ammunition warehouses, not identified archaeologically (Aragón, 1810). However, according to historians, the settlement was massively burnt by this attack, particularly the chapel (e.g., Fontana, 1873; Biedma, 1905; Barba Ruiz, 2000; Lanöel et al., 1974). Two years after the fire, the locality was re-occupied by the expeditionary Welshman Henry Libanus Jones, who was searching for seals and wild cattle (1812-1823). He describes an adobe-tile roof building near the beach, with an oven assigned to the bakery, together with two further constructions over and

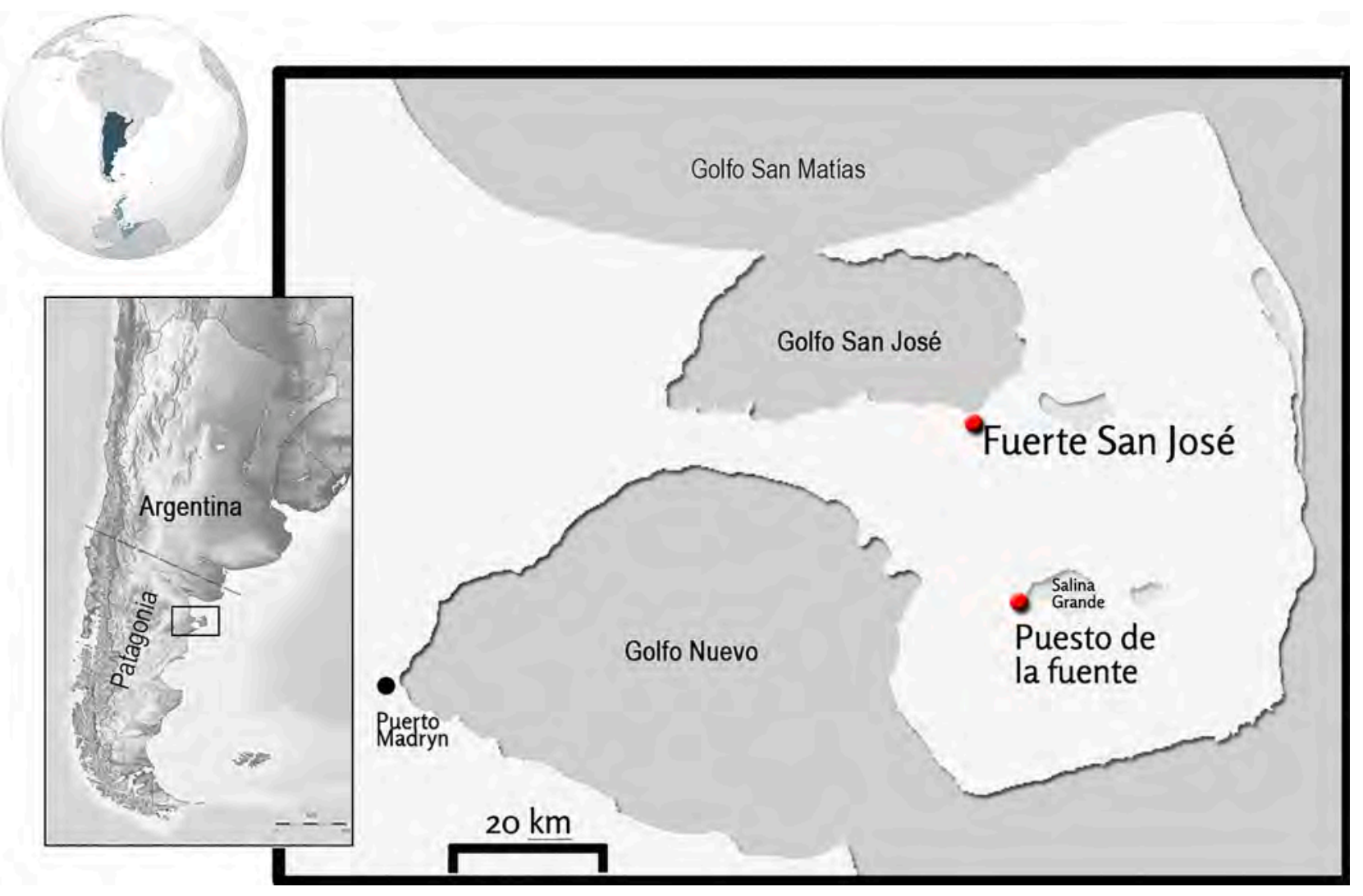

Fig. 1. The Fuerte San José location (Península Valdés, Province of Chubut, Argentina). 


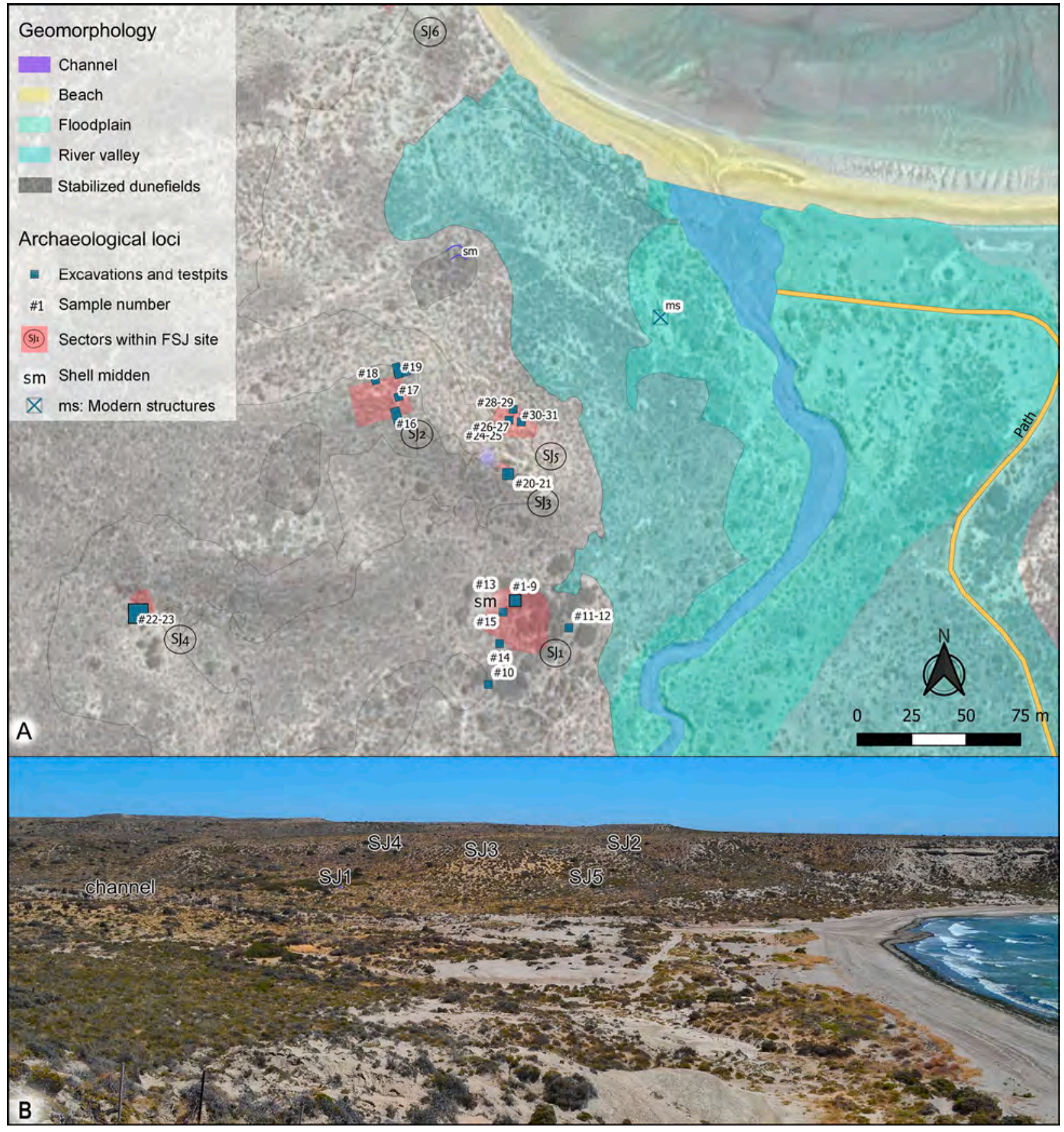

Fig. 2. A- Topographic and geomorphological map of the Fuerte San José (following Bouza et al., 2017a). Archaeological sectors can be broadly described as follow (Bianchi Villelli et al., 2019): S1 = central area; S2 = small fort; SJ3 = adobe-wall foundation (unknown functionality); SJ4 = small cemetery; SJ5 = dumpsite; and SJ6 = reworked archaeological material. Sample locations are numbered \#1 to \#31. B- View of the locality from the east, including archaeological sectors.

down a hill, with thatched-roof and adobe with thatched-roof (interpreted as the chapel), respectively (Jones, 1891). The installation of a small village near the Fuerte San José at the beginning of the 20th century, along with subsequent vandalism, unsystematic private excavations and tourism, have reduced the colonial site to few visible and scarce remains.

Regarding the archaeological study, analyses of the type and density of cultural remains, features, vegetation and topographic characteristics allowed identifying six functionally distinct areas at the Fuerte San José, named San José 1 to 6 (SJ1-SJ6) (Fig. 2A, B). The SJ1, placed at a relatively densely vegetated foothill bordered by a channel, may correspond to the area where most population was established. The SJ2, located over a hill facing the beach, comprises a $20 \mathrm{~m}$-side quadrangular structure bordered by a ditch (Fig. 3B), probably related to the "small fort" described in historical records, which might have been surrounded by a palisade. The SJ3 sector, placed at the eastern foot-hill of SJ2, corresponds to a $3 \times 1.5 \mathrm{~m}$ depression surrounded by an adobe-wall foundation. This feature of unknown functionality comprises the only architectural remain of the archaeological site (Fig. 3C). Human remains of European origin at SJ4 allow to define it as a small cemetery area (García Guráieb et al., 2017), which is also reported in documents (Viedma, 1779), whereas a sort of dumpsite could have existed at SJ5. Finally, SJ6 is interpreted as reworked cultural materials due to fluvial processes recorded by the presence of extensive gullies (Bianchi Villelli et al., 2019) and, therefore, sediments from this sector were not considered here. 


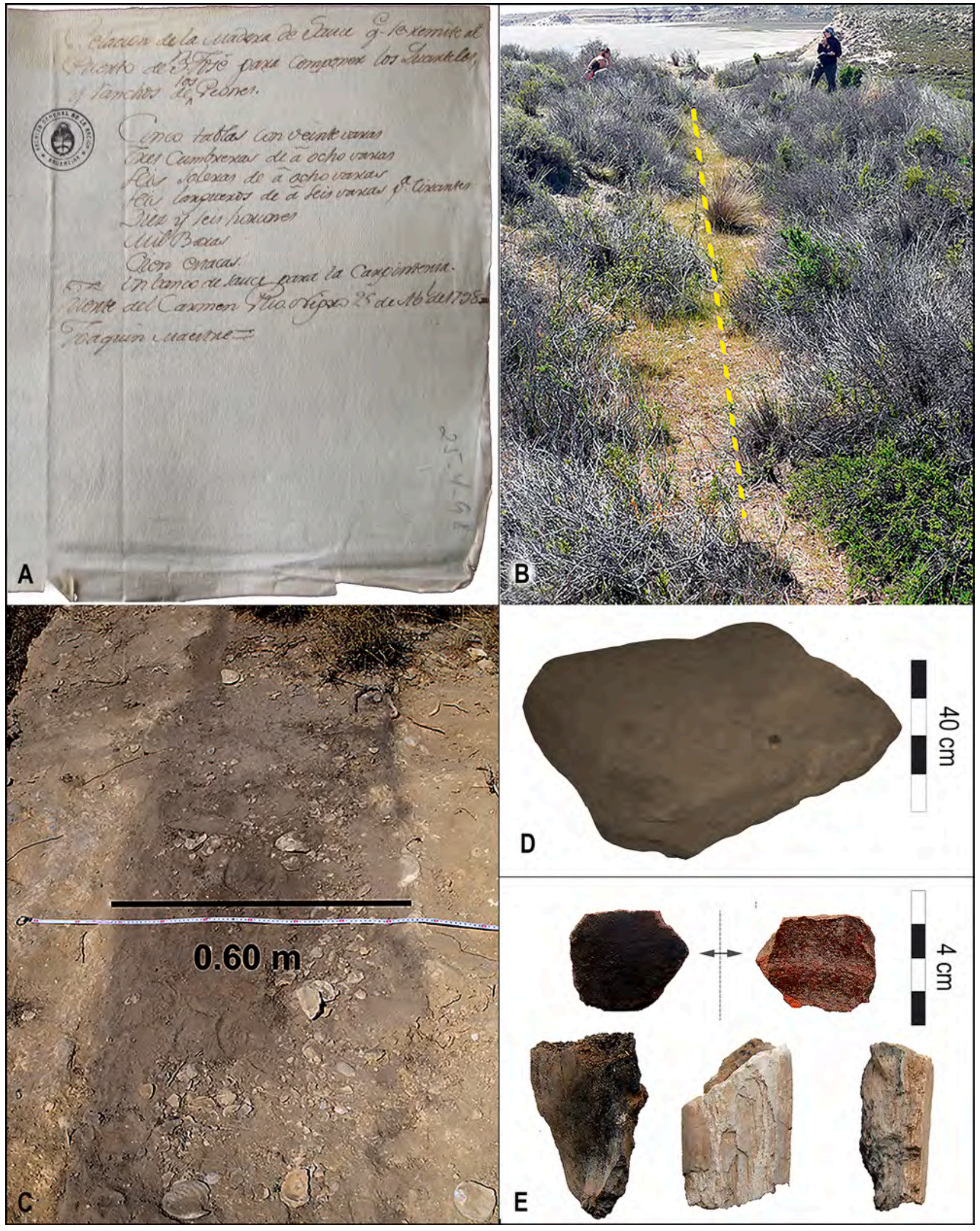

Fig. 3. A- Documentary record from the Fuerte San José describing the need of willow wood to repair quarters and dwellings. It also details a list of construction items for walls and roof. April, 25 of 1797. Relevant archaeological features: B- perimeter ditch from the small fort (SJ2). C- the adobe-wall foundation (SJ3). Dadobe brick exhibited at the "Centro de Interpretación Istmo Ameghino" (sample \#32). Examples of thermoaltered archaeological remains: E- domestic vessel used for cooking (SJ1), and F- large mammal bone fragments from the dumpsite area (SJ5). 
Archaeological evidence was found mainly on surface and up to 20 $\mathrm{cm}$ depth. The highest frequency and diversity of the archaeological record is observed in the SJ1 sector, followed by SJ5, SJ6, SJ2 and SJ4 sectors. The remains comprise bones and mollusk shells $(\mathrm{N}=4743)$, a variety of ceramics mostly for domestic use $(\mathrm{N}=748)$, metal fragments $(\mathrm{N}=610)$, glasses $(\mathrm{N}=188)$, and few stone artifacts $(\mathrm{N}=28)$ (Bianchi Villelli et al., 2019). Despite the high degree of fragmentation, bone weathering stages are low, accounting for rapid burial conditions. Finally, the frequency of thermo-altered archaeological remains is low, comprising few ceramics (8.5\%) and archaeofaunistic record (1.6\%) (Bianchi Villelli et al., 2019). This evidence provides no conclusive insights, since thermo-alteration could be the result of cooking, manufacturing and/or discarding processes.

On the other hand, the archaeological record of the Fuerte San José shows few thermoaltered ceramics (8.5\%) and archaeofaunistic record (1.6\%) (Bianchi Villelli et al., 2019). This evidence provide no conclusive insights, since thermoalteration could be the result of cooking, manufacturing and/ or discarding processes.

\subsection{The past extensive open-air fire and their archaeological expectations at the Fuerte San José}

Combustion features like hearths, kilns, ovens and different intentional or un-intentional space-circumscribed fire structures has been studied archaeologically to answer questions related to the hominization process, pyrotechnologies, intensity of human occupation, resource management, conflagration events, space functionality and taphonomic processes. A this regard, different analytical techniques were applied, such as clay X-ray diffraction, thermoluminensce, anthracology, soil micromorphology, geochemistry, FTIR spectroscopy and infrared analysis, among others (e.g., Karkanas et al., 2002; Berna et al., 2007, 2012; Mallol et al., 2007; Goldberg et al., 2009; Brodard et al., 2012; March et al., 2014; Gur-Arieh et al., 2014; Morley, 2017; Villagran et al., 2017; Ozán et al., 2019; Shahack-Gross et al., 2018). To a lesser extent, past combustion features have been tackled by magnetic analyses to discuss paleotemperatures, the geomagnetic field evolution (i.e., archaeomagnetism) and postdepositional processes (e.g., Ellwood et al., 1998; Dalan, 2008; Brodard et al., 2012; Kapper et al., 2014; Morley, 2017; Ozán et al., 2015, 2017, 2019; Shahack-Gross et al., 2018; Urban et al., 2019). Due to space-circumscribed combustions often took place repeatedly through time, they present a high archaeological visibility, whereas physicochemical characteristics of thermoaltered sediments contrast remarkably with the off-site or natural control area.

In contrast, the usually low archaeological visibility of past extensive open-air fires resulting from singular or less redundant combustion episode, as in the case of this work, poses an additional methodological challenge. Consequently, studies are very scarce and usually related to Soil Sciences or lacustrine/ mire-based paleoenvironmental reconstructions (e.g., Certini, 2005; Whitlock and Larsen, 2002; De Bano et al., 2005; Berna et al., 2007; Friesem et al., 2014; Robin and Nelle, 2014), whereas only a few uses magnetic properties (Gedye et al., 2000; Jordanova et al., 2001; Certini, 2005). The low visibility of an extensive open-air fire not only responds to the fact that it is often a singular episode, but to the soil insulating capacity which causes a heat penetration of only few centimeters (e.g., Certini, 2005; Berna et al., 2007). Therefore, mineralogical changes triggered by temperature will depend on the preservation of such thin soil-surface layer and the charred material and ash remained on surface. The preservation and intensity of thermoaltered signatures will be subject to the degree of vegetation cover, the presence of anthropogenic combustible materials (e.g., architecture, furniture's, objects, commodities, etc.), $\mathrm{pH}$ and soil composition (e.g., abundance of clays and/ or Fe-bearing minerals), climate and geomorphological processes (e.g., humidity, temperature, wind transport capacity, natural fire occurrence, topography, etc.) (Certini, 2005; Théry-Parisot et al., 2010; Friesem et al., 2014; Shahack-Gross, 2018).
Taken into consideration documentary and archaeological data, concepts related to the fire behavior and characteristics of the regional setting exposed above, some expectations regarding the preservation of the magnetic-soil thermoalteration resulting from the supposed historical fire, and its magnitude, are proposed. On one hand, a low preservation of a magnetic-soil thermoalteration (Section 2) is expected at the population core (SJ1), where the most leather and thatch-made structures reported in the documents should have been placed. In a fire, open and highly combustible features, like leather-huts, release heat upwards, inhibiting a flameover reaction (i.e., when the fire convection is inhibits by a roof, causing heat radiation downwards). In this scenario, a weak soil-mineral modification -if any- is expected, affecting only few centimeters in depth that could be easily eroded by the wind. Only if a very intense ignition source (e.g., multiple and/ or repeated intentional focus) and extra-fuel needed to keep the fire burning for a long time might have existed, a durable magnetic-mineral modifications could be expected at SJ1 (e.g., Certini, 2005). Same preservation expectancy are proposed to the small cemetery (SJ4) and dumpsite areas (SJ5), though bones remains with low weathering degrees found in the latter (Bianchi Villelli et al., 2019).

On the other hand, a moderate to high preservation of thermoaltered-soils is expected in the small fort (SJ2) and the adobewall foundation (SJ3), since these sectors probably comprised roofbearing structures and/ or places with an extra-fuel availability (e.g., palisade) capable of producing a prolonged fire. In turn, closed structures favor the flameover reaction, responsible to increase the heat conduction to the floor (e.g., Harrison, 2013; March et al., 2014; Shahack-Gross, 2018). In addition, bones recovered at SJ2 show low weathering stages (Bianchi Villelli et al., 2019), suggesting a rapid burial which in turn could have preserved burnt sediments. A set of sediment samples of SJ2 were also taken from a ditch (Fig. 3B; Table 1), a natural trap which might have behaved against erosion (Friesem et al., 2014) beyond the high-wind exposition registered in SJ2 (Fig. 2). Unfortunatellly, the other buildings elusively mentioned in the documents (i.e., gunpowder storage places, kitchens, the hospital and the chapel) were not recognized archaeologically yet. However, due to the reason exposed above, their fire preservation expectative should be rather high, especially the case of the chapel and gunpowder storage places.

In sum, a single fire episode of $1810 \mathrm{AD}$ at the Fuerte San José could have been sufficient to leave a distinguishable (Section 2) and durable soil-magnetic signature in the small fort (SJ2) and the adobe-wall foundation (SJ3). However, such distinct soil-magnetic signature would be expected in the population core (SJ1), the small cemetery (SJ4) and the dumpsite area (SJ5) only if a high-magnitude fire might have taken place.

\section{Methodology and theoretical framework}

\subsection{Materials and techniques}

A total of 31 sediment samples taken from poor-developed A and C soil horizons were analyzed (Fig. 2A), plus a sample of an adobe (\#32, mudbrick) from the Fuerte San José. The latter was obtained from a local exhibition at the "Centro de Interpretación Istmo Ameghino" (Fig. 3D; Table 1). A broad macroscopic characterization comprised texture (by feel, USDA triangle) and color determinations (dry, Munsell Color Chart). Total organic (\%TOC) and inorganic carbon (\%TIC), as indirect data of organic matter and calcium carbonates percentages, respectively, were also quantified by loss-on-ignition (Heiri et al., 2001). Due to conspicuous magnetic results of samples \#20 and \#21, two thin sections of single grains were included.

Given magnetic anomalies and location, 10 out of 32 samples were selected to heat at four temperatures aiming to study local magnetic responses (Section 2.4.). Magnetic analysis of both raw (\#) and heated samples (E\#) comprised measurements of magnetic susceptibility at room temperature (RT) at two frequencies $(1000 \mathrm{~Hz}$ and $16,000 \mathrm{~Hz})$, by 
Table 1

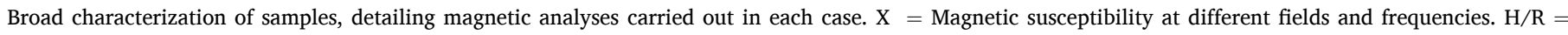

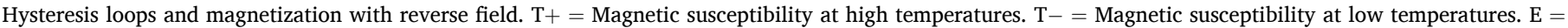
Sample chosen for the experiment. \%TOC = percentage of total organic carbon. \%TIC = percentage of total inorganic carbon.

\begin{tabular}{|c|c|c|c|c|c|c|c|}
\hline Sector/context & $\begin{array}{l}\text { Sample } \\
\#\end{array}$ & $\begin{array}{l}\text { Bulk depth } \\
(\mathrm{cm})\end{array}$ & Color (dry) & $\begin{array}{l}\% \\
\text { TOC }\end{array}$ & $\% \mathrm{TIC}$ & Texture & $\begin{array}{l}\text { Magnetic } \\
\text { analyses }\end{array}$ \\
\hline \multirow[t]{15}{*}{ SJ1 (population core), between hills. } & $\# 1$ & 5 & 2.5 Y $5 / 2$ grayish brown & 0,497 & 0,328 & loam & $\mathrm{X}$ \\
\hline & $\# 2$ & 12 & 2.5 Y $5 / 2$ grayish brown & 0,937 & 0,540 & sandy loam & $\mathrm{X}$ \\
\hline & $\# 3$ & 18 & 2.5 Y $5 / 2$ grayish brown & 0,829 & 0,358 & loam & $\mathrm{X}$ \\
\hline & \#4 & 9 & 2.5 Y $5 / 2$ grayish brown & 0,811 & 0,423 & sandy loam & $\mathrm{X}, \mathrm{H} / \mathrm{R}$ \\
\hline & \#5 & 18 & 2.5 Y $5 / 2$ grayish brown & 0,827 & 0,451 & sandy loam & $\mathrm{X}, \mathrm{H} / \mathrm{R}$ \\
\hline & \#6 & 22 & $\begin{array}{l}2.5 \text { Y } 6 / 2 \text { light brownish } \\
\text { gray }\end{array}$ & 0,937 & 0,220 & sandy loam & $\mathrm{X}, \mathrm{H} / \mathrm{R}, \mathrm{E}$ \\
\hline & \#7 & 5 & 2.5 Y 4/1 dark gray & 1,611 & 0,117 & loamy sand & $\mathrm{X}, \mathrm{H} / \mathrm{R}, \mathrm{T}+, \mathrm{T}-$ \\
\hline & $\# 8$ & 13 & 2.5 Y $5 / 2$ grayish brown & 0,841 & 0,201 & sandy loam & $\begin{array}{l}\mathrm{X}, \mathrm{H} / \mathrm{R}, \mathrm{T}+, \mathrm{T}-\text {, } \\
\mathrm{E}\end{array}$ \\
\hline & $\# 9$ & 16 & 2.5 Y $5 / 2$ grayish brown & 0,492 & 0,273 & sandy loam & $\mathrm{X}$ \\
\hline & $\# 10$ & 45 & $\begin{array}{l}2.5 \text { Y } 6 / 2 \text { light brownish } \\
\text { gray }\end{array}$ & 0,830 & 0,491 & sandy loam & $\mathrm{X}, \mathrm{H} / \mathrm{R}, \mathrm{E}$ \\
\hline & $\# 11$ & 18 & 2.5 Y 6/1 Gy & 0,880 & 0,253 & sandy loam & $\mathrm{X}$ \\
\hline & $\# 12$ & 36 & $\begin{array}{l}2.5 \text { Y } 6 / 2 \text { light brownish } \\
\text { gray }\end{array}$ & 0,876 & 0,202 & silt loam & $\mathrm{X}$ \\
\hline & $\# 13$ & 17 & 2.5 Y $5 / 2$ grayish brown & 0,763 & 0,304 & sandy loam & $\mathrm{X}$ \\
\hline & $\# 14$ & 13 & $\begin{array}{l}2.5 \text { Y } 6 / 2 \text { light brownish } \\
\text { gray }\end{array}$ & 1,018 & 0,302 & silt loam & $\mathrm{X}$ \\
\hline & $\# 15$ & 11 & 2.5 Y $5 / 2$ grayish brown & 0,912 & 0,333 & loam & $\mathrm{X}$ \\
\hline $\begin{array}{l}\text { SJ2 (small fort area), over a hill, facing the beach, southern ditch } \\
\text { side. }\end{array}$ & $\# 16$ & 54 & $\begin{array}{l}2.5 \text { Y } 6 / 2 \text { light brownish } \\
\text { gray }\end{array}$ & 0,999 & 0,675 & sandy loam & $\mathrm{X}, \mathrm{H} / \mathrm{R}$ \\
\hline \multirow[t]{2}{*}{ SJ2 (small fort area), over a hill, facing the beach. } & $\# 17$ & 20 & $\begin{array}{l}2.5 \text { Y } 6 / 2 \text { light brownish } \\
\text { gray }\end{array}$ & 0,430 & 1,447 & sandy loam & $\mathrm{X}, \mathrm{H} / \mathrm{R}, \mathrm{E}$ \\
\hline & $\# 18$ & 36 & $\begin{array}{l}2.5 \text { Y } 6 / 2 \text { light brownish } \\
\text { gray }\end{array}$ & 1,143 & 3,128 & sandy loam & $\mathrm{X}, \mathrm{H} / \mathrm{R}$ \\
\hline $\begin{array}{l}\text { SJ2 (small fort area), over a hill, facing the beach, northern ditch } \\
\text { side. }\end{array}$ & $\# 19$ & 50 & $\begin{array}{l}2.5 \text { Y } 6 / 2 \text { light brownish } \\
\text { gray }\end{array}$ & 0,687 & 1,284 & sandy loam & $\mathrm{X}$ \\
\hline \multirow[t]{2}{*}{ SJ3 (adobe-wall foundation), foot-hill. } & $\# 20$ & 3 & 2.5 Y $6 / 3$ & 0,845 & 9,527 & silt loam & $\begin{array}{l}\mathrm{X}, \mathrm{H} / \mathrm{R}, \mathrm{T}+, \mathrm{T}-\text {, } \\
\mathrm{E}\end{array}$ \\
\hline & $\# 21$ & 30 & 2.5 Y 5/1 Gy & 2,864 & 1,153 & sandy loam & $\begin{array}{l}\mathrm{X}, \mathrm{H} / \mathrm{R}, \mathrm{T}+, \mathrm{T}-\text {, } \\
\mathrm{E}\end{array}$ \\
\hline \multirow[t]{2}{*}{ SJ4 (small cemetery area), over a hill. } & $\# 22$ & 45 & $\begin{array}{l}2.5 \text { Y } 6 / 2 \text { light brownish } \\
\text { gray }\end{array}$ & 0,360 & 0,374 & loam & $\mathrm{X}$ \\
\hline & $\# 23$ & 39 & $\begin{array}{l}2.5 \text { Y } 6 / 2 \text { light brownish } \\
\text { gray }\end{array}$ & 0,744 & 0,234 & sandy loam & $\mathrm{X}, \mathrm{H} / \mathrm{R}, \mathrm{E}$ \\
\hline \multirow[t]{8}{*}{ SJ5 (dumpsite area), on hill slope. } & $\# 24$ & 30 & $\begin{array}{l}2.5 \text { Y } 6 / 2 \text { light brownish } \\
\text { gray }\end{array}$ & 0,692 & 1,080 & sandy loam & $\mathrm{X}$ \\
\hline & $\# 25$ & 46 & 2.5 Y $5 / 2$ grayish brown & 1,499 & 3,572 & sandy loam & $\mathrm{X}$ \\
\hline & $\# 26$ & 34 & 2.5 Y $5 / 2$ grayish brown & 1,034 & 5,835 & sandy loam & $\mathrm{X}, \mathrm{H} / \mathrm{R}$ \\
\hline & $\# 27$ & 47 & $\begin{array}{l}2.5 \text { Y } 6 / 2 \text { light brownish } \\
\text { gray }\end{array}$ & 1,034 & 6,797 & sandy loam & $\mathrm{X}, \mathrm{H} / \mathrm{R}, \mathrm{E}$ \\
\hline & $\# 28$ & 30 & 2.5 Y $5 / 2$ grayish brown & 0,570 & 0,631 & sandy loam & $\mathrm{X}$ \\
\hline & $\# 29$ & 40 & $\begin{array}{l}2.5 \text { Y } 6 / 2 \text { light brownish } \\
\text { gray }\end{array}$ & 0,595 & 0,835 & loam & $\mathrm{X}$ \\
\hline & $\# 30$ & 17 & $\begin{array}{l}2.5 \text { Y } 6 / 2 \text { light brownish } \\
\text { gray }\end{array}$ & 0,782 & 1,119 & loam & $\mathrm{X}, \mathrm{H} / \mathrm{R}, \mathrm{E}$ \\
\hline & $\# 31$ & 32 & $\begin{array}{l}2.5 \text { Y } 6 / 2 \text { light brownish } \\
\text { gray }\end{array}$ & 0,815 & 0,716 & sandy loam & $\mathrm{X}, \mathrm{H} / \mathrm{R}, \mathrm{E}$ \\
\hline $\begin{array}{l}\text { Adobe brick from the local exhibition at the Centro de } \\
\text { Interpretación I. Ameghino, }\end{array}$ & \#32 & - & 2.5 Y 5/1 Gy & 2,315 & 0,582 & $\begin{array}{l}\text { silt clay } \\
\text { loam }\end{array}$ & $\mathrm{X}, \mathrm{H} / \mathrm{R}$ \\
\hline
\end{tabular}

- different fields (5-700 A/m), at about 20 steps (Section 2.2.). For this purpose, an AGICO-Multifunction Kappabridge Instrument (model MFK1-FA) was used, in sediments $<500 \mu \mathrm{m}$ dried for three days overnight at $40^{\circ} \mathrm{C}$. Results were normalized to mass and averaged to be used in the frequency-dependent susceptibility parameter equation: $\% \mathrm{X}_{\mathrm{FD}}=$ $100\left(\mathrm{X}_{\mathrm{LF}}-\mathrm{X}_{\mathrm{HF}}\right) / \mathrm{X}_{\mathrm{LF}}$ (Dearing et al., 1996; Hrouda, 2011).

For two samples with relatively high $\% \mathrm{X}_{\mathrm{FD}}$ result, and two others control samples with lower $\% \mathrm{X}_{\mathrm{FD}}$, low-temperature susceptibility (RT to $-190.8^{\circ} \mathrm{C}$ ) and thermal variations of the susceptibility (RT to $700{ }^{\circ} \mathrm{C}$ ) analyses were performed, by using liquid nitrogen and an argon atmosphere, respectively (Sections 2.2 and 2.3). Both measurements were run in an AGICO-Multifunction Kappabridge Instrument. Additionally, a set of 17 representative samples from the archaeological site were chosen to analyze hysteresis loops and the magnetization with reverse field using a vibrating sample magnetometer (VSM, Molspin- Ltd.).

\subsection{Superparamagnetic minerals: The $\% X_{F D}$ parameter and susceptibility at low temperatures}

Fine-grain particles corresponding to SP and single-domain (SD) magnetites/maghemites are produced by pedogenetic (e.g., Maher and Thompson, 1991; Heller and Evans, 1995) and combustion processes (e. g., Dearing et al., 1996; Worm, 1998; Liu et al., 2005; Dalan, 2008; Torrent et al., 2006; Hrouda, 2011; Shahack-Gross et al., 2018). Particularly, the production of SP/ SD grains due to combustion depends on the parent material, organic matter, porosity, duration and intensity 
of the fire, sample depth, etc. Such complex variable system makes the well-known expectations (Fig. 4) only a general guide for the analysis and interpretation of natural soils.

Here, the calculation of SP particles is based on the $\% \mathrm{X}_{\mathrm{FD}}$ parameter, a proxy which relates the magnetic susceptibility of low and high frequencies (Dearing et al., 1996; Hrouda, 2011) (Section 2.1). According to Dearing et al. (1996), results around 6-12\% may suggest the presence of significant content of SP magnetite grains. However, lower $\% \mathrm{X}_{\mathrm{FD}}$ values do not necessarily indicate a lesser SP content, since SP grain interactions could cause grain aggregations with a magnetic behavior of coarser grains (Maher and Taylor, 1988). Moreover, a significant quantity of detrital pseudo-single domain (PSD) and multi-domain (MD) particles, as well as high amounts of paramagnetics and antiferromagnetics could also decrease the \% $\mathrm{X}_{\mathrm{FD}}$ (Dearing et al., 1996; Pan et al., 2000; Hrouda, 2011). Therefore, different lines of evidence should be considered to cross-check the type and size of magnetic minerals in natural samples.

Finally, since the $\% \mathrm{X}_{\mathrm{FD}}$ roughly detects SP grains between $\sim 20$ and $30 \mathrm{~nm}$, four samples (\#7, \#8, \#20 and \#21) were selected to explore the susceptibility at low temperatures (Section 2.1). This test can account for the presence of SP grains $<20 \mathrm{~nm}$ (see theoretical framework in Vásquez et al., 2009, 2018).

\subsection{Magnetic susceptibility at high temperatures and VSM measurements}

High-temperature measurements of magnetic susceptibility were carried out in four samples (\#7, \#8, \#20 and \#21) to test past thermoalteration processes (e.g., Jordanova et al., 2001; Kapper et al., 2014; Shahack-Gross et al., 2018). Broadly, in non-heated materials, the magnetic susceptibility during heating and cooling is different, due to
Fe-bearing minerals (e.g., magnetite, hematite, clays) show compositional changes after heating (e.g., Hrouda et al., 2003; Liu et al., 2005). Since these compositional changes are non-reversible, re-heating cannot modify the magnetic mineralogy again, so thermomagnetic curves are similar.

In order to broadly characterize the mineralogy, concentration and size of magnetic minerals, hysteresis loops and the magnetization with reverse field were also measured (Section 2.1.). The VSM yields accurate and fast information about the paramagnetic susceptibility $\left(\mathrm{X}_{\text {para }}\right)$, saturation remnant magnetization (Mrs), saturated magnetization (Ms), coercivity of remanence (Hcr) and coercivity (Hc). While extensive parameters $\left(\mathrm{X}_{\mathrm{para}}, \mathrm{Mrs}\right.$ and $\left.\mathrm{Ms}\right)$ give information about the ferrimagnetic fraction (i.e., magnetite, titanomagnetite, maghemite), Hcr and Hc parameters provide insights into the anti-ferromagnetic minerals (e.g., hematite, goethite).

In general, the formation of ferrimagnetic minerals is expected to occur with combustion (from $200{ }^{\circ} \mathrm{C}$, but mainly over $500{ }^{\circ} \mathrm{C}$ ) under certain REDOX conditions and the presence of organic matter (e.g., Schwertmann and Taylor, 1989; Ketterings et al., 2000; Certini, 2005; Oldfield and Crowther, 2007; Churchman et al., 2006) (Fig. 4A, B). Concerning the anti-ferromagnetic fraction, dehydroxilation processes may also occur in goethite or ferrihydrite at low temperatures $(\sim 150$ / $300{ }^{\circ} \mathrm{C}$ ), causing either the formation of hematite (Rooksby, 1961), ultra-fine maghemite or magnetite, depending on $\mathrm{Eh}, \mathrm{pH}$ and organic matter conditions (e.g., Ketterings et al., 2000; Liu et al., 2005; Certini and Scalenghe, 2006; Churchman et al., 2006; Torrent et al., 2006). The magnetic signature of paramagnetic minerals (i.e., Fe-rich clays or Fecarbonates) with temperature is unclear and may vary substantially depending on the initial mineralogy. For instance, magnetite was produced out of siderite at $400{ }^{\circ} \mathrm{C}$ (e.g., Pan et al. 2000), whereas in the case

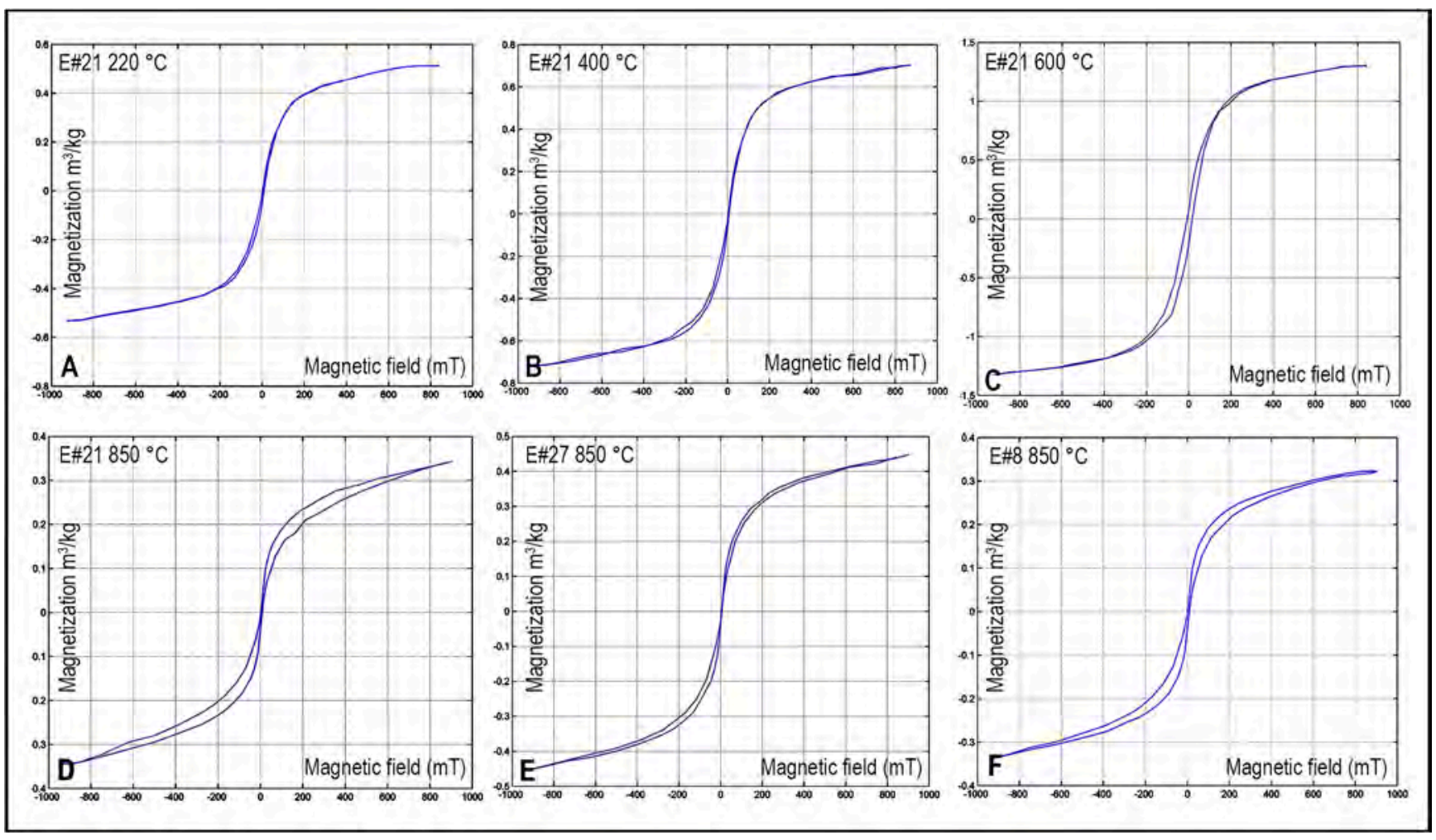

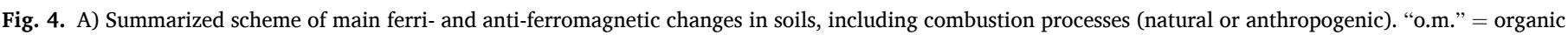

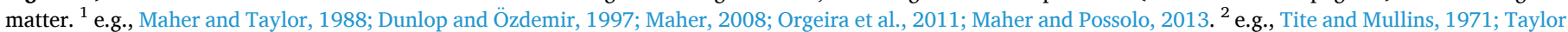

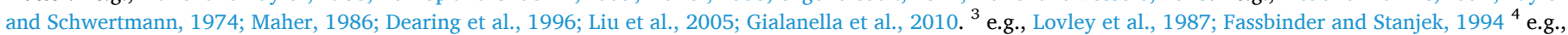

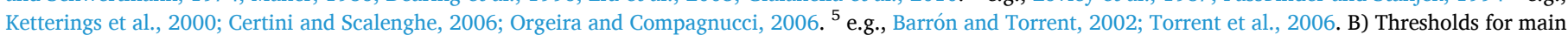

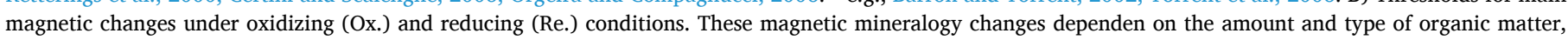

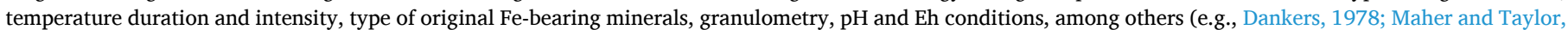
1988; De Boer, 1999; Ketterings et al., 2000; Liu et al., 2005; Torrent et al., 2006; Orgeira and Compagnucci, 2006). 
of Fe-rich clays, changes are expected to occur at about $400{ }^{\circ} \mathrm{C}$ (i.e., dehydroxilation), but mostly after $600{ }^{\circ} \mathrm{C}$, when the complete destruction of the mineral structure occurred (e.g., Ulery et al., 1996; Certini, 2005 and references therein) (Fig. 4B).

\subsection{The experiment}

Ten samples from the assemblage were selected and heated under oxidizing conditions at different temperatures (Supplementary material, Table 1) to explore thresholds in which local sediments show changes in their magnetic mineralogy. Reducing conditions could be produced by the burning of organic matter (e.g., Maher and Taylor, 1988), however, the case under study shows low \%TOC values, so the oxidizing atmosphere used in the experiment comprises a good analogue to the presumed local fire. Each sample was divided into four sub-samples (total of 40), one of which was heated at $220^{\circ} \mathrm{C}, 400{ }^{\circ} \mathrm{C}, 600{ }^{\circ} \mathrm{C}$ and $850{ }^{\circ} \mathrm{C}$ for one hour. To analyze SP formation, the $\% \mathrm{X}_{\mathrm{FD}}$ parameter was calculated in all samples (Section 2.2.). Hysteresis loops and the isothermal remanent magnetization with back field were also carried out for a set of samples (E\#7, E\#8 and E\#21 at four temperatures). Additionally, to corroborate reversible behavior thresholds, the magnetic susceptibility at high temperature was performed in sample \#21 (Section 2.3).

\section{Results}

\subsection{Magnetic mineralogy characterization of raw samples}

With minor variations, sediments under study correspond to light brownish grey well-sorted fine sands. Contributions of finer materials define textural variations among sandy loams, loamy sands and silt clay loams. Along with a well sorting, they indicate aeolian deposition, in agreement with geomorphologic and climatic descriptions (Bouza et al., 2017a; Coronato et al., 2017). On the whole, \%TOC values are very low (0.95\%), with relatively high concentrations (1.5-2.99\%) in samples $\# 7$, \#21, \#25, and \#32. The average \%TIC is also low ( $<1.37 \%)$, though with few moderate contributions (3.13-6.8\%) in samples \#18, \#25, \#26 and \#27; and a peak (9.53\%) in \#20. Full data of magnetic analyses presented below are included in the Supplementary material, Tables 1-5.

The mean $X$ at low frequencies is about $3.8 \cdot 10^{-8} \mathrm{~m}^{2} / \mathrm{kg}$, whereas samples \#5, \#17, \#27 and \#30 show values significantly higher, and samples \#20, \#21 and \#32 are considerable below this value (Fig. 5). Such differences in the magnetic fraction are related to the mineralogy, concentration and/ or particle size, and may indicate different sediment sources and/ or distinctive post-depositional processes. By considering the spatial distribution of the $\mathrm{X}$ along the archaeological site, the small fort (SJ2) and the adobe-wall foundation (SJ3) comprise X anomalies.

The contribution of $\% \mathrm{X}_{\text {para }}$ measured in 17 samples shows values $<$ $3 \%$, where \#17, \#20, \#21 and \#32 present the highest values, most likely due to major Fe-rich clays content (Fig. 5). This result is also observed in the high-field upper slope branch of hysteresis loops (Fig. 6B-D). The Ms and Mrs parameters show values above the mean for samples \#18, \#26, \#27 and \#30, likely related to a relative high concentration and/ or coarse fraction of ferrimagnetics.

The Hcr shows small variations across the assemblage (15-36 mT), broadly indicating low concentrations of anti-ferromagnetic minerals, particularly in samples \#17, \#26, \#27 and \#30. The Hc does not show significant variations either, though moderate higher values are observed in samples \#5, \#21 and \#32, related to anti-ferromagnetic minerals. Two mineral populations with distinct coercivities (e.g., hematite plus magnetite) and/ or the combination of SD and SP minerals (e.g., Roberts et al., 1995; Tauxe et al., 1996) are suggested for hysteresis loops with a slightly wasp-waisted shape (\#8, \#10, \#16, \#23, \#26, \#30, \#32) (Fig. 6).

The calculation of the $\% \mathrm{X}_{\mathrm{FD}}$ which indicates SP minerals (25-30 nm) yields ranges between 3.2 and 5.1\% (Fig. 7), thus a low content of SP particles and/ or a high proportion of PSD/ MD ferrimagnetics (Dearing et al., 1996) can be inferred. Exceptionally, the \#21 shows a value slightly above the $6 \%$ threshold $(6.21 \%)$, suggesting a significant presence of SP particles. Notably, $\% \mathrm{X}_{\mathrm{FD}}$ values are not correlated with the total X (Fig. 7), then post-depositional processes might have transformed the original detrital ferrimagnetic minerals into SP particles in \#21, and likely in $\# 20$, whose $\% \mathrm{X}_{\mathrm{FD}}$ is just below the $6 \%$ threshold (5.1\%).

Measurements of $\mathrm{X}$ at low temperatures also show that sample \#21 present SP particles $(<25 / 30 \mathrm{~nm}$ ) (Fig. $8 \mathrm{~A}$ ), as it is observed in the

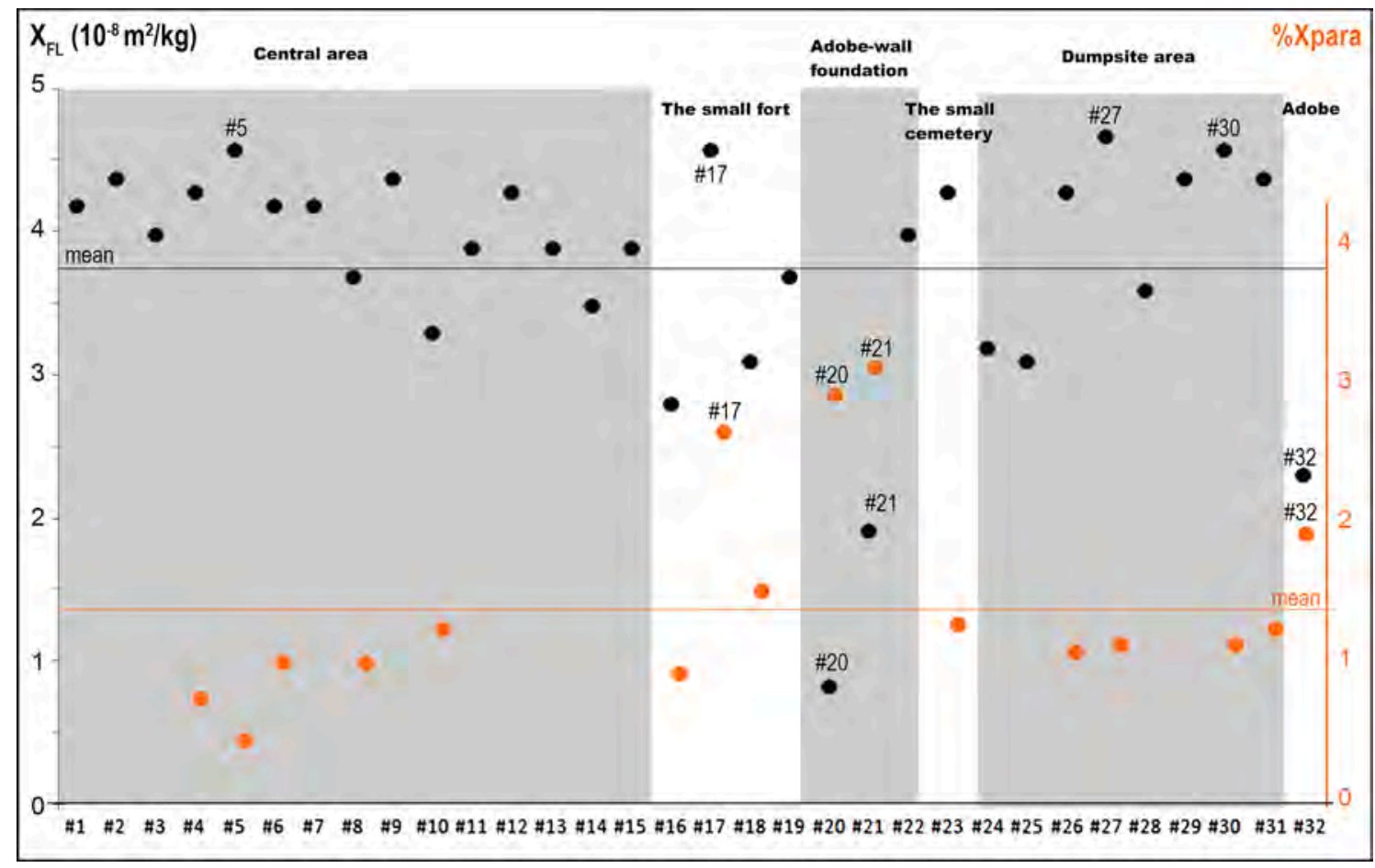

Fig. 5. Magnetic (black primary axis) and paramagnetic (orange secondary axis) susceptibilities of raw samples. 


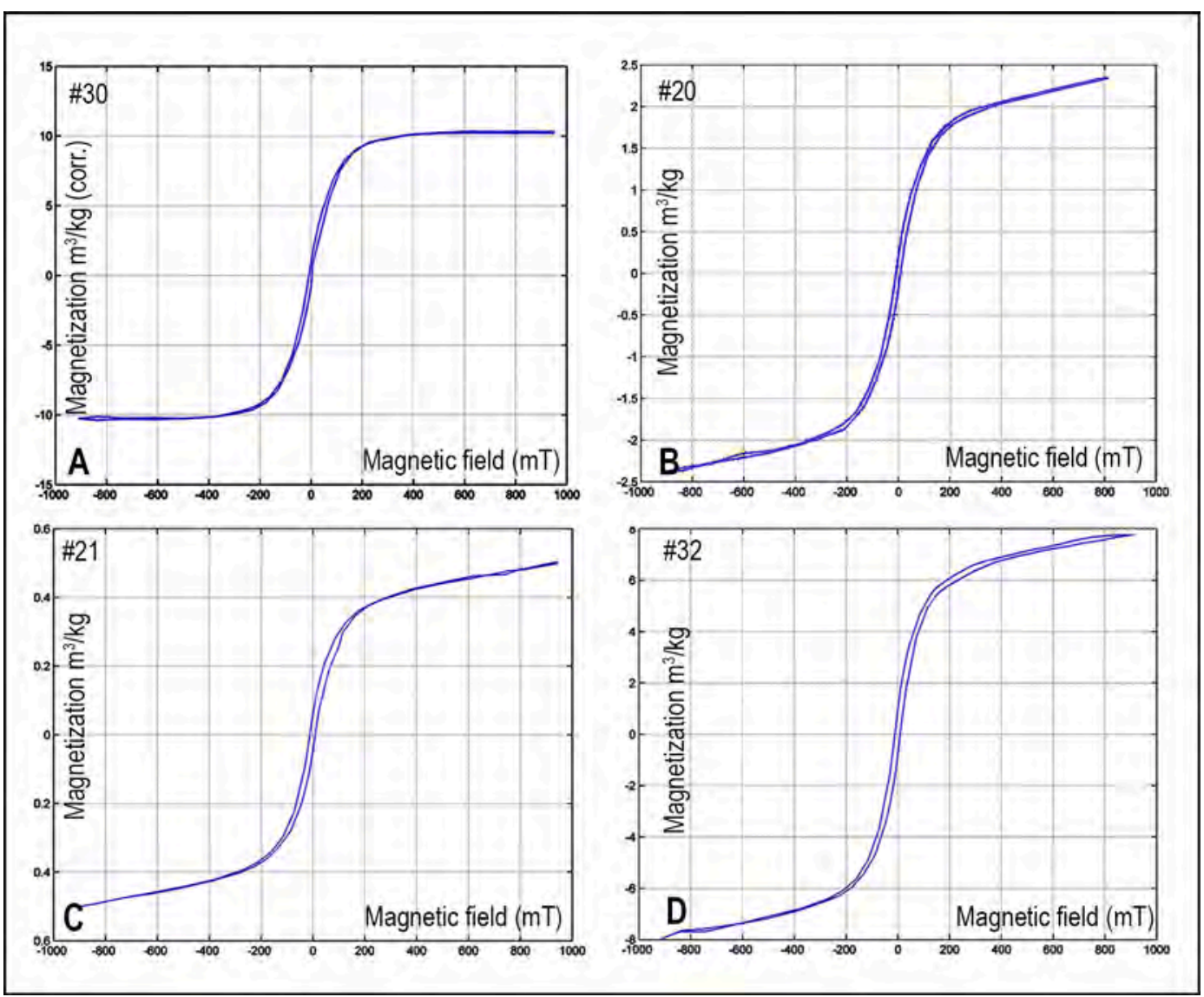

Fig. 6. Representative hysteresis loops of: A- a slightly wasp-waisted shape. B, C and D- undetermined shapes with presence of paramagnetic susceptibility.

\section{$\% X_{F D}$}

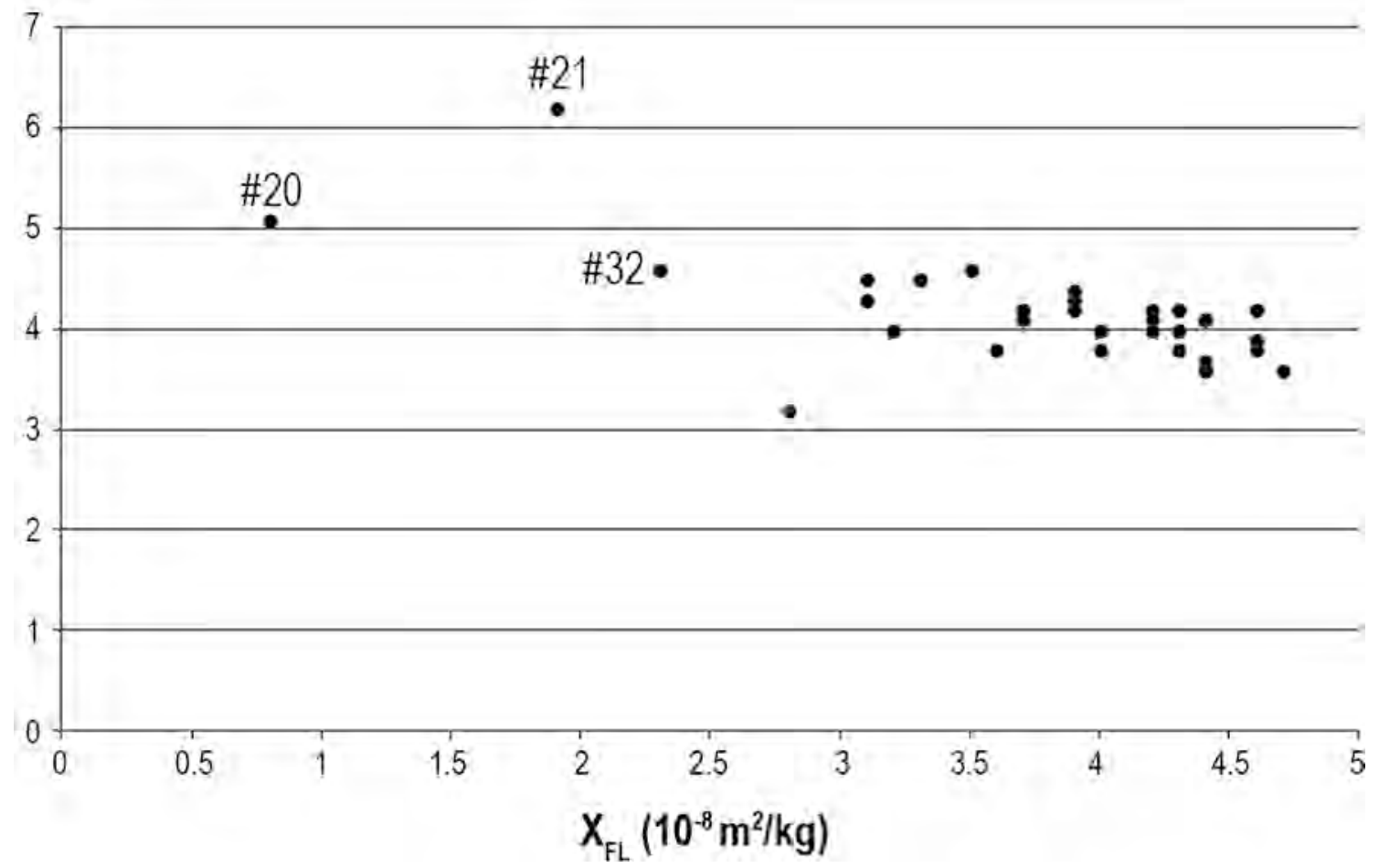

Fig. 7. $\% \mathrm{X}_{\mathrm{FD}}$ against $\mathrm{X}$. 

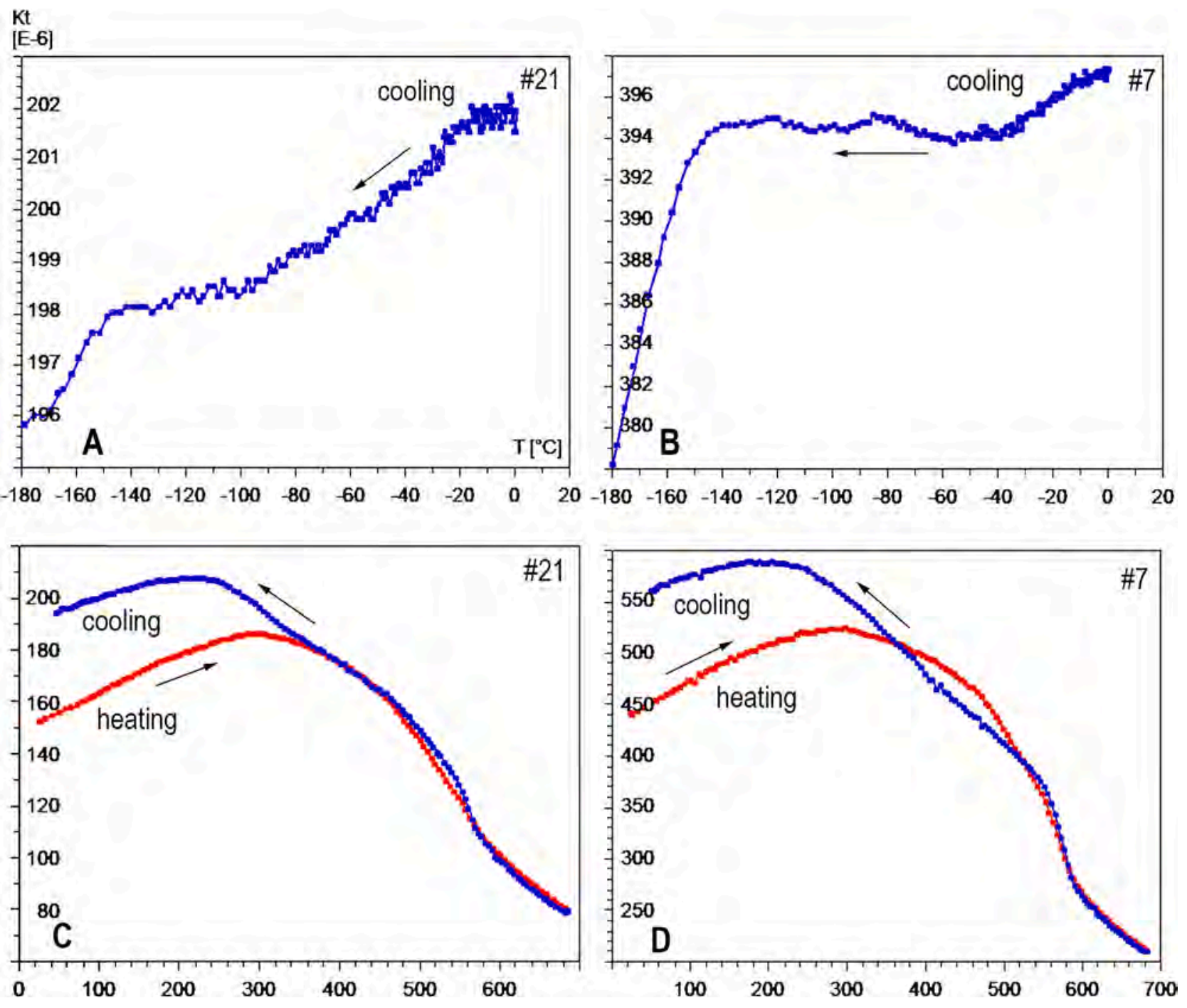

Fig. 8. Representative examples of thermomagnetic curves of magnetic susceptibility at low (A-B) and high (C-D) temperatures.

positive linear correlation between temperature and X (Liu et al., 2005; Vásquez et al., 2009). Along with the presence of detrital MD magnetite, the wide Verwey transition of sample $\# 21$ (at $-150^{\circ} \mathrm{C}$ ) may also suggest the presence of maghemite (Dunlop, 2002; Hrouda et al., 2003). Likewise, the $X$ at low temperature in samples \#7 (Fig. 8B), \#8 and \#20 would point out the presence of MD magnetite and maghemite, though these curves are not necessarily indicative of SP particles.

Finally, the $X$ at high temperatures measured in four samples (\#7, \#8, \#20, \#21) shows non-reversible behaviors, thus a lack of previous thermoalteration can be inferred (Fig. 8C, D). However, the \#21 shows a slightly different behavior, indicating reversibility up to $\sim 350{ }^{\circ} \mathrm{C}$ (Fig. 8C). The wide Curie temperature of all analyzed samples (at $\sim 580{ }^{\circ} \mathrm{C}$ ), could be related to mineral mixtures and/ or the presence of Ti-poor titanomagnetites.

\subsection{Magnetic mineral alteration in experimental samples}

Except for the E\#20, experimental samples heated at different temperatures show a clear change in color, towards reddish tonalities. This evidence that oxidation processes and hematite formation took place inside the furnace, as expected. Broadly, the $\mathrm{X}$ shows an increase up to $400{ }^{\circ} \mathrm{C}$, and then a substantial decrease from $600^{\circ} \mathrm{C}$ to $850{ }^{\circ} \mathrm{C}$ (Fig. 9A). This trend could be explained by the formation of fine-grain magnetite and/ or maghemite up to $400{ }^{\circ} \mathrm{C}$. Then, hematite is formed under oxidizing conditions after $580 / 640{ }^{\circ} \mathrm{C}$ (i.e., magnetite/ maghemite Curie temperature), triggering a $\mathrm{X}$ decrease (Fig. 4).

Interestingly, the E\#20 behaves differently, since the $\mathrm{X}$ decreases until $600{ }^{\circ} \mathrm{C}$, showing a maximum at $850^{\circ} \mathrm{C}$. This fact could be explained by exceptional reducing conditions within the furnace (inside the melting pot) favored by $\mathrm{CO}_{2}$ loss due to the $\mathrm{CaCO}_{3}$ destruction (note that the \#20 presents a significantly higher \%TIC value and the E\#20 at $850{ }^{\circ} \mathrm{C}$ does not present a reddish color). Reducing conditions prevent hematite formation and promote fine-grain magnetite/ maghemite minerals (Fig. 4), which explains the $\mathrm{X}$ increase at $850{ }^{\circ} \mathrm{C}$. One could thus suggest that the presence of carbonates, similarly to organic matter, can cause reducing conditions within soil micro-environments.

An increase of the $\% \mathrm{X}_{\mathrm{para}}$ of E\# 8, E\#21 and E\#27 with temperature is registered (Fig. 9B), along with an inverse relationship with extensive parameters ( $\mathrm{X}, \mathrm{Ms}$ and $\mathrm{Mrs}$ ). Higher $\% \mathrm{X}_{\text {para }}$ with temperature are also registered in the upper slope branch of hysteresis loops (Fig. 10). One possible explanation of this trend is that Fe released from Fe-rich clays after $600{ }^{\circ} \mathrm{C}$ (e.g., Ulery et al., 1996; Certini, 2005) may form Fecarbonates with stronger paramagnetic susceptibilities.

The Hcr increases with temperature in all the three cases, indicating a concentration of high-coercivity minerals (Fig. 11). The Hc also increases with temperature until $600{ }^{\circ} \mathrm{C}$ and then drops at $850{ }^{\circ} \mathrm{C}$, probably due to textural changes. The mixture of ferri- and antiferromagnetic minerals is revealed in the hysteresis loops by clear 


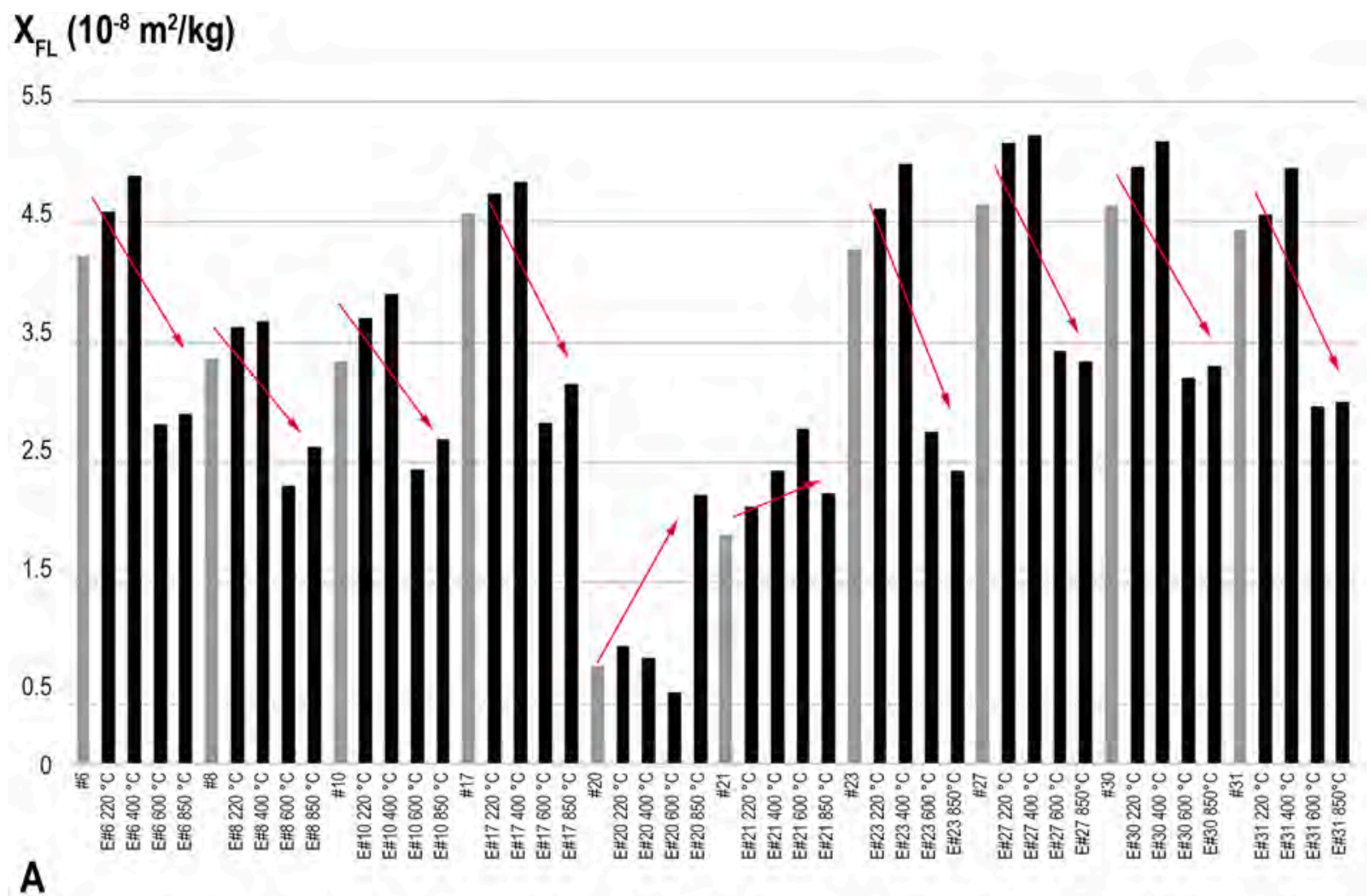

\section{\%Xpara}

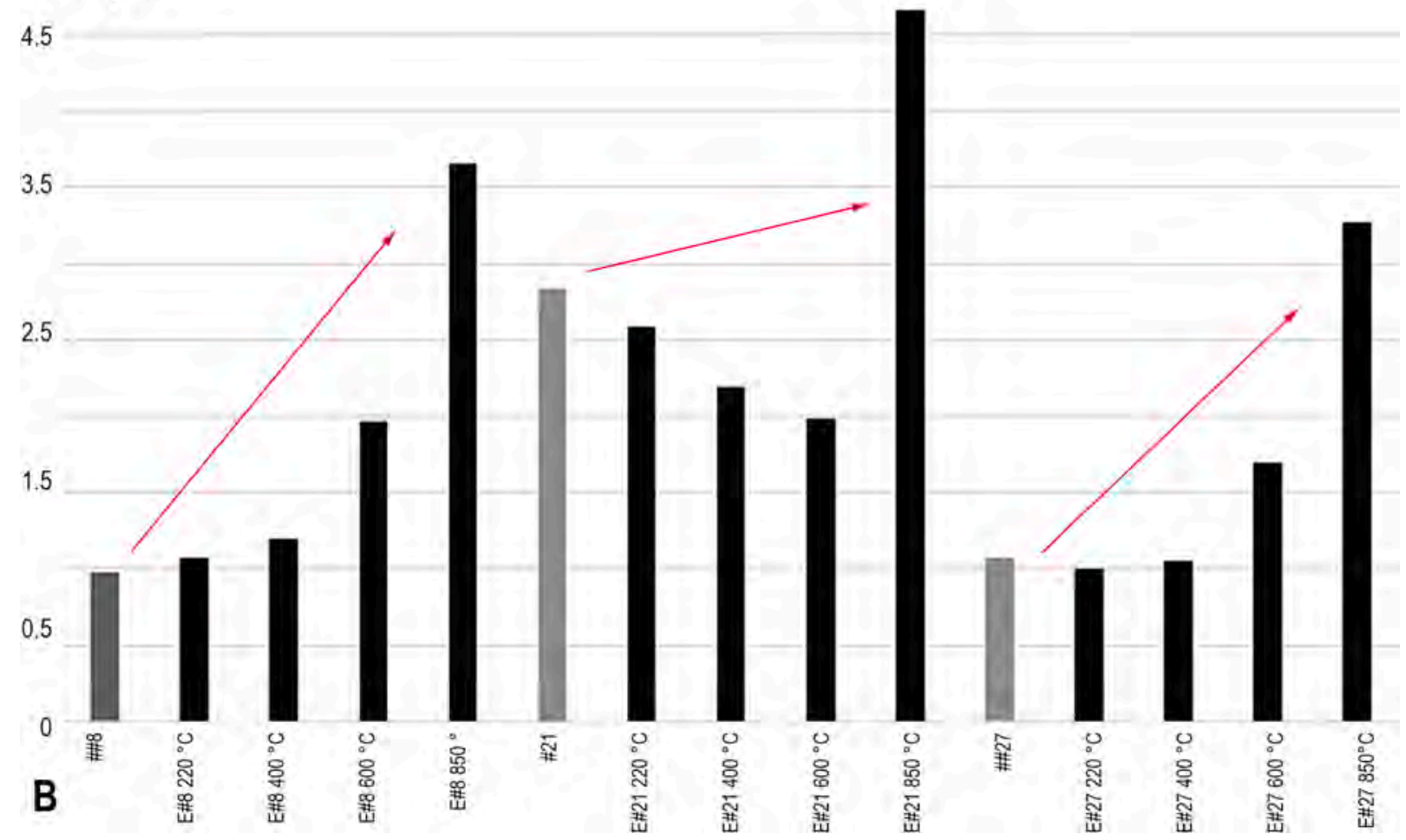

Fig. 9. A- magnetic and B- paramagnetic susceptibility of the experimental samples (grey columns correspond to the raw samples).

wasp-waisted shapes in samples heated at $850{ }^{\circ} \mathrm{C}$ (Fig. 10).

Experimental samples indicate an increase of the $\% \mathrm{X}_{\mathrm{FD}}$ with temperature (Fig. 12A), in a non-linear trend. A conspicuous drop of the $\%$ $\mathrm{X}_{\mathrm{FD}}$ at $600{ }^{\circ} \mathrm{C}$ is also observed, likely attributed to textural changes. Again, in \#27, the significant decrease of this parameter at $850^{\circ} \mathrm{C}$ could be attributed to grain-size changes (Maher and Taylor, 1988; Dearing et al., 1996). Even if this increase on the $\% \mathrm{X}_{\mathrm{FD}}$ suggest a relative increase on SP, the absolute content of SP grains in heated samples remain rather low due to the poor-ferrimagnetic mineralogy of raw samples. This fact along with the increasing contribution of anti-ferro- and paramagnetic 


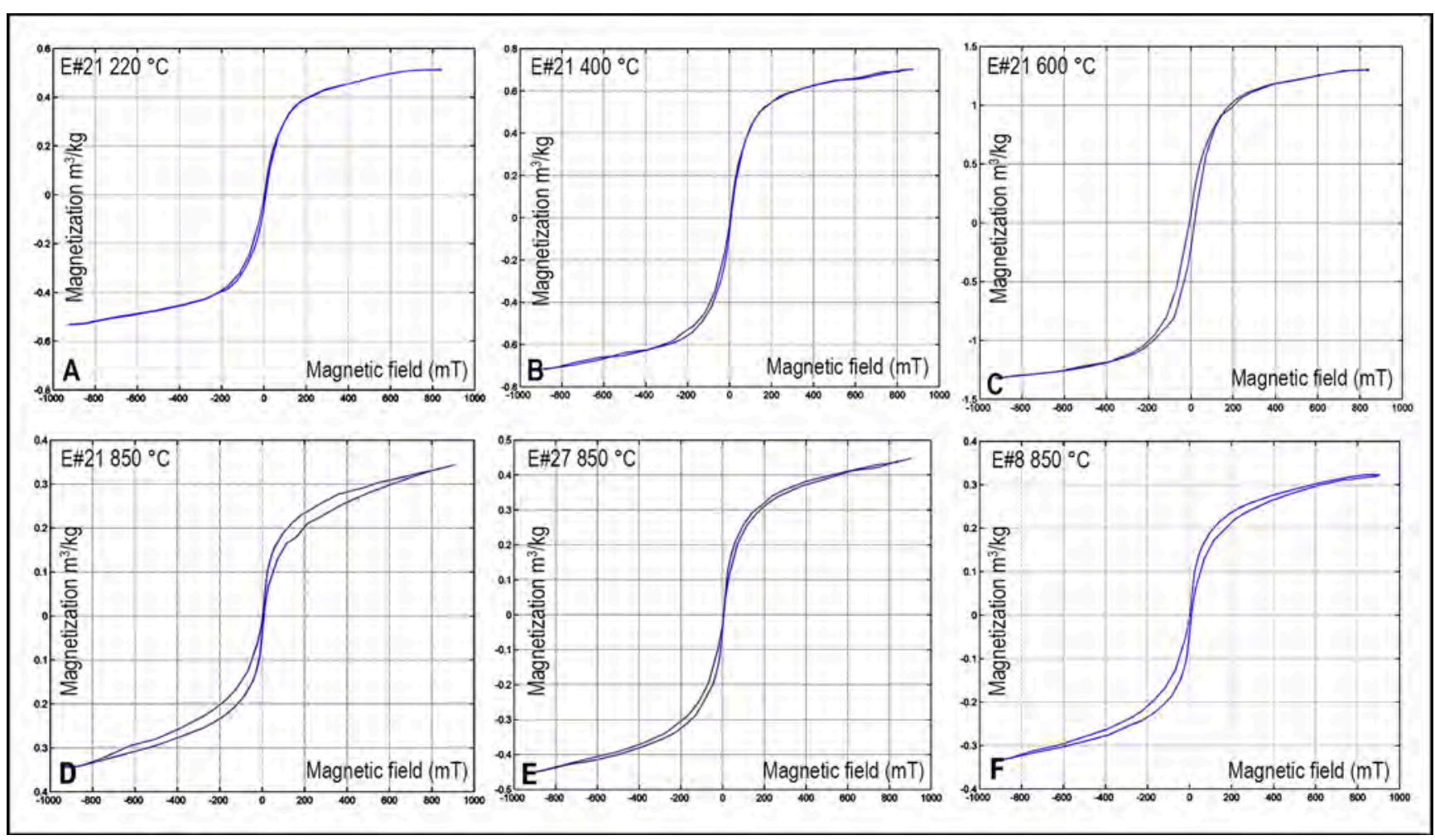

Fig. 10. Representative hysteresis loops of experimental samples. A to D- progression with temperature in E\#21. Note the increasingly defined wasp-waited shapes with temperature and the more pronounced upper slope branch indicating the presence of paramagnetic susceptibility. E and F- strong wasp-waited shapes in samples burnt at $850^{\circ} \mathrm{C}$.

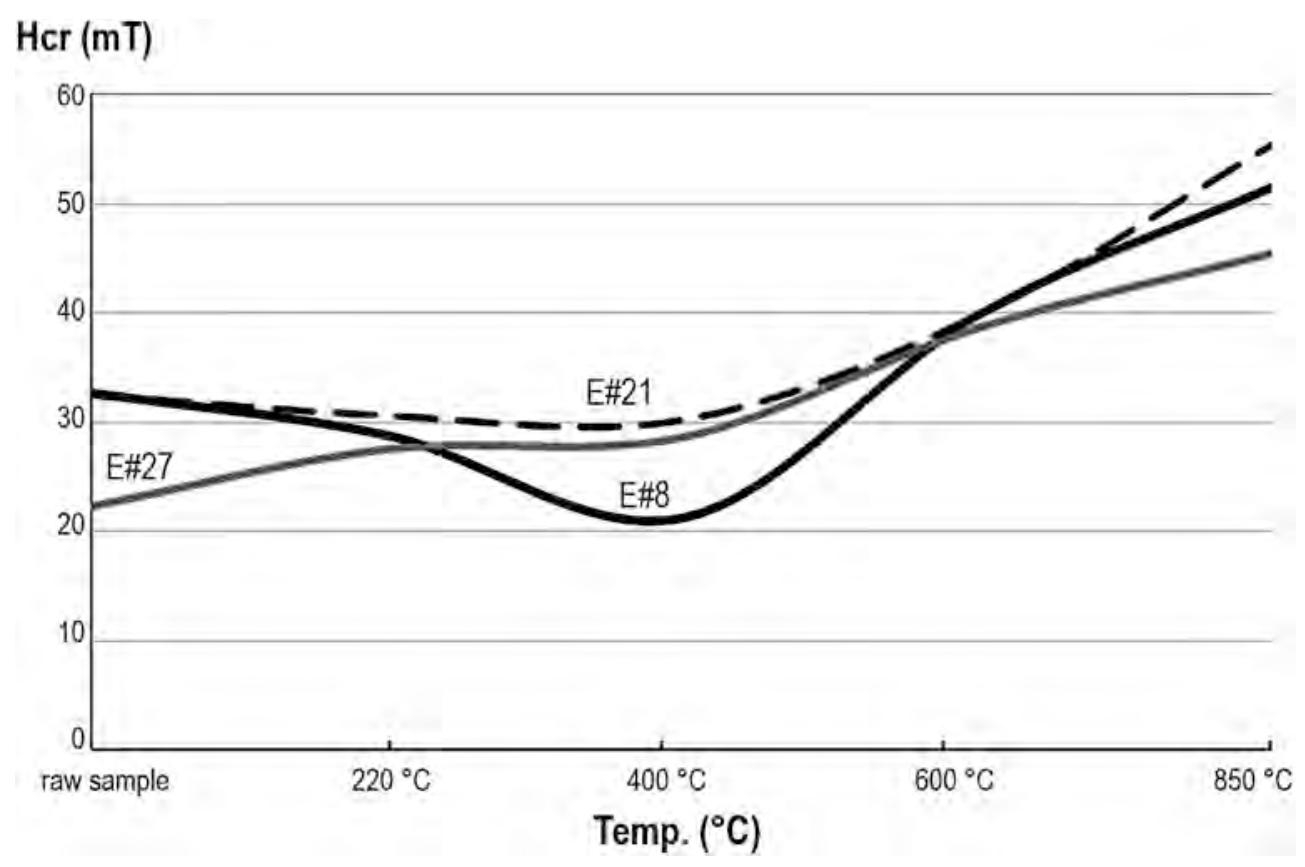

Fig. 11. Hcr against temperature in three selected samples.

minerals to the total $\mathrm{X}$ as temperature rise could explain the lack of correlation between $\mathrm{X}$ and $\% \mathrm{X}_{\mathrm{FD}}$ (Fig. 12B).

Finally, thermomagnetic curves of the E\#21 heated at four temperatures indicate that the reversibility related to the thermoalteration of magnetic minerals is outlined around $400{ }^{\circ} \mathrm{C}$ (Fig. 13). At $850{ }^{\circ} \mathrm{C}$, the curve shows a paramagnetic behavior, so a substantial decrease of ferrimagnetic minerals attributed to oxidation processes is inferred.

\section{Discussion}

\subsection{Magnetic signals of thermoalteration processes}

Magnetic analyses in raw samples indicate that sediments across the Fuerte San José present low $X$, a contribution of $X_{\text {para }}$ below 3\% (Fig. 5) and also low content of anti-ferromagnetic minerals. However, taking all 


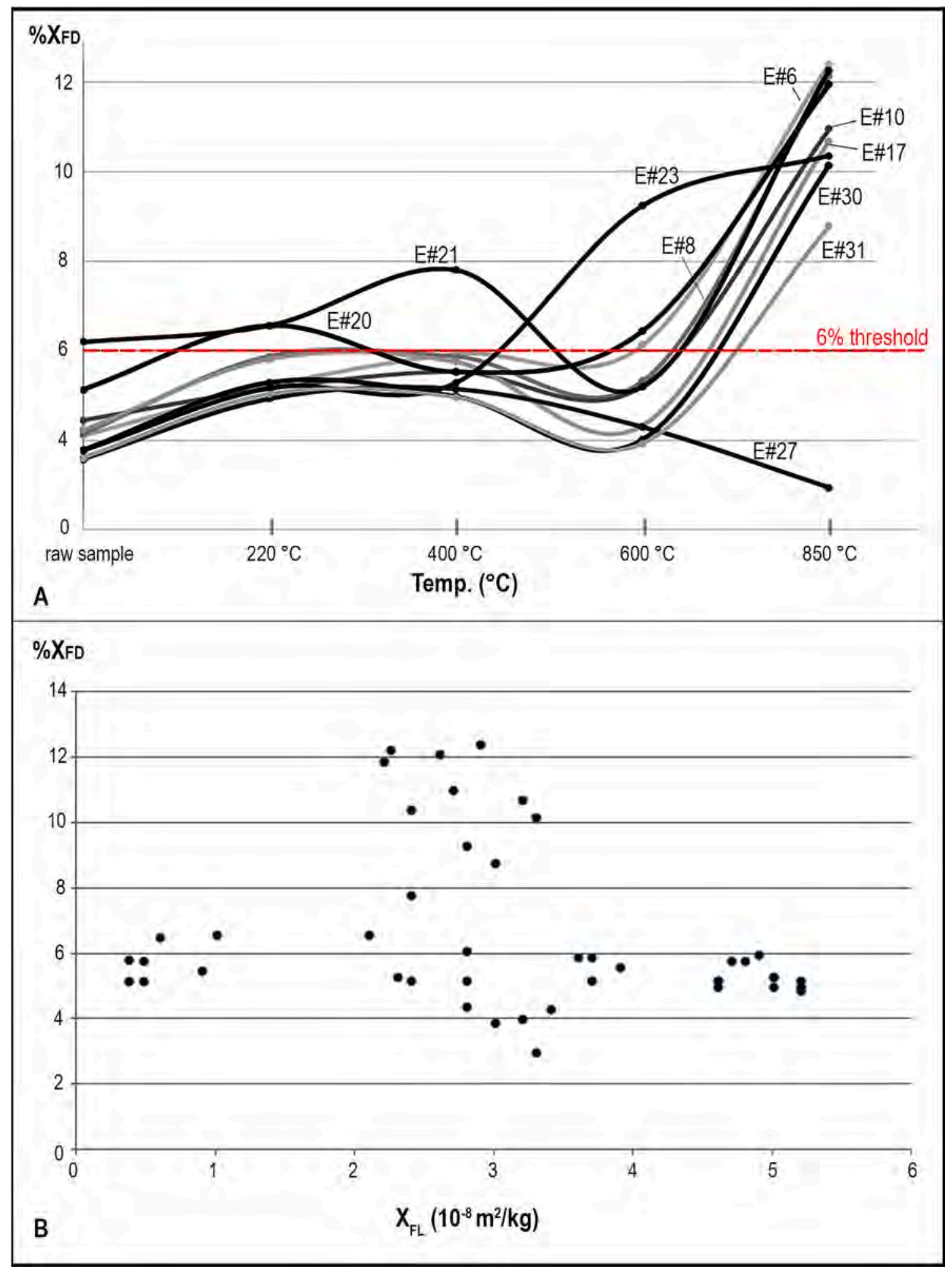

Fig. 12. A- the $\% \mathrm{X}_{\mathrm{FD}}$ parameter from the ten experimental samples heated at four temperatures, including raw samples. $\mathrm{B}$ - the $\% \mathrm{X}_{\mathrm{FD}}$ against the total $\mathrm{X}$.

the analyses into consideration, some samples depict a distinctive magnetic/ mineralogical behavior. For instance, the \#17 (the small fort) presents a relative high content of ferrimagnetics (magnetite, titanomagnetite, maghemite) and paramagnetics (e.g., Fe-rich clays), whereas the \#20 (the adobe-wall foundation, upper sample) shows a weak X (but a quantity of SP grains above the average) and a relatively high content of Fe-rich clays (Figs. 5 and 7). The \#21 (the adobe-wall foundation, lower sample) is the most anomalous case, also with a weak X, but with a significant amount of SP grains. This sample also shows relatively high Fe-rich clay content and a relatively higher concentration of highcoercivity minerals (e.g., hematite, goethite) (Figs. 5, 7, and 8A). Finally, except for the presence of SP, the \#32 (the adobe) has a similar behavior to \#21 (Figs. 5 and 7).

The presence of SP grains in soils is associated to combustion and/ or pedogenetic processes, if iron-bearing minerals are available (Fig. 4). Since arid and cold conditions of the study area do not favor soil 

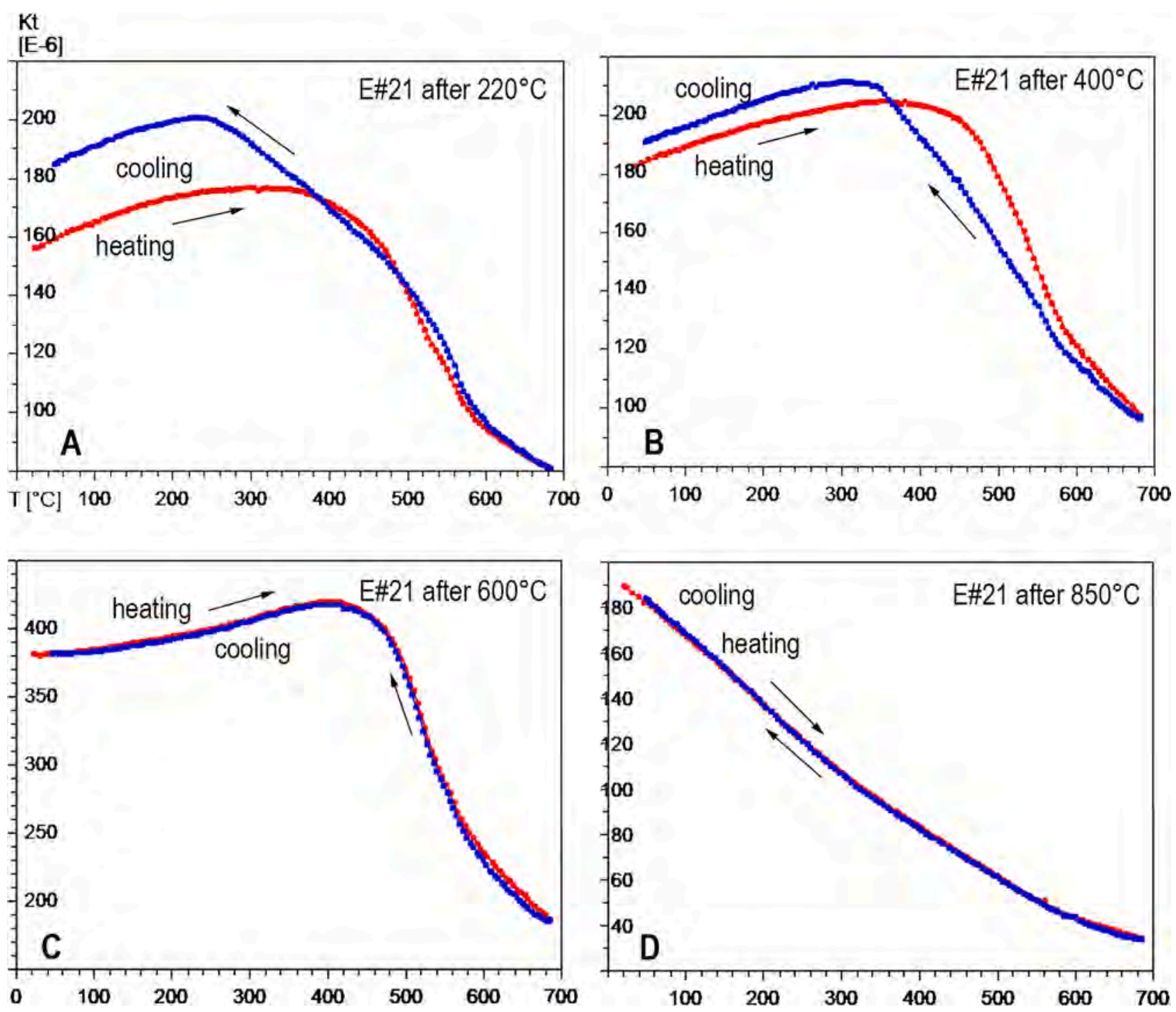

Fig. 13. Susceptibility at high temperatures of samples E\#21 burnt at four temperatures.

development (Bouza et al., 2017a) as it is below the $300 \mathrm{~mm}$ precipitation threshold (Maher and Thompson, 1991; Maher and Possolo, 2013), the concentration of SP grains associated with pedogenesis can be ruled out here (e.g., Mullins, 1971; Maher and Taylor, 1988; Fassbinder and Stanjek, 1994; Orgeira et al., 2011). Moreover, the presence of volcanic glass was not registered in the locality thereby SP grains cannot be associated with titanomagnetites contained in the glass either (Ozán et al., 2019). Considering this scenario, SP grains in raw samples are most likely to thermoalteration processes.

The $\% \mathrm{X}_{\mathrm{FD}}$ calculated for experimental samples showed SP grains formation under oxidizing conditions already at low temperatures of $220{ }^{\circ} \mathrm{C}$ during only one hour, thus indicating that fine-grain ferrimagnetics can be easily produced by heating in the sediments under study. These experimental results account for raw samples interpretation, where a significant presence of SP grains is only registered in \#21 and suggested in \#20 (Figs. 2, 3B, 7). These results fit well with the expectations proposed above (Section 1.3.), where the sector SJ3 should preserve signal of thermoalteration.

Consistently, small fragments of burnt bones and charcoal are observed in the \#21 thin section (Fig. 14A-C). Note that available historical information does not report the inclusion of ash or charcoal as adobe temper (Tello and Sanz Sanz, 1994), so their presence can be interpreted as postdepositional. The sample \#20, located just above the
\#21, registers "calcitic-ash" (Fig. 14D), $\mathrm{CaCO}_{3}$ associated with burning and subsequent post-depositional processes occurring in the calcium of some plant cellular minerals, (e.g., Iglesias et al., 1997; Canti, 2003; Friesem et al., 2014) (note that high \%TIC values in \#20 were recorded). This ashy deposit could be the result of woody plan remains associated to a thatch roof of such adobe structure (Kreimerman and ShahackGross, 2019), whose preservation could have been favored by the regional aridity and alkaline soils (Friesem et al., 2014). In fact, the willow wood reported in documents (Fig. 3A) could have produced such ashy deposit as it contains calcium crystals and calcium oxalates (Arihan and Güvenç, 2011; Petrochenko et al., 2019).

The existence of SP grains $<20 \mathrm{~nm}$ in \#21 was also corroborated by the $\mathrm{X}$ at low temperature, nonetheless it does not show the expected reversibility in thermo-magnetic curves (Fig. 8A, D). Experimental samples indicate that the reversible behavior takes place after $400{ }^{\circ} \mathrm{C}$ (Fig. 13B). If combustion processes occurred in \#21, therefore temperature should have been below $400{ }^{\circ} \mathrm{C}$. In fact, fire temperatures in surface and shallow $(<10 \mathrm{~cm})$ soils in areas with scarce fuel beds, seldom reaches temperatures above $300{ }^{\circ} \mathrm{C}$ (e.g., Gedye et al., 2000; Certini, 2005; De Bano et al., 2005; Certini and Scalenghe, 2006). Burn experiments carried out on adobe structures with vegetal roofs also indicate an indoor temperature of about $400{ }^{\circ} \mathrm{C}$ and floor-sediments under $500{ }^{\circ} \mathrm{C}$ (Forget et al., 2015; Kreimerman and Shahack-Gross, 2019). In this 


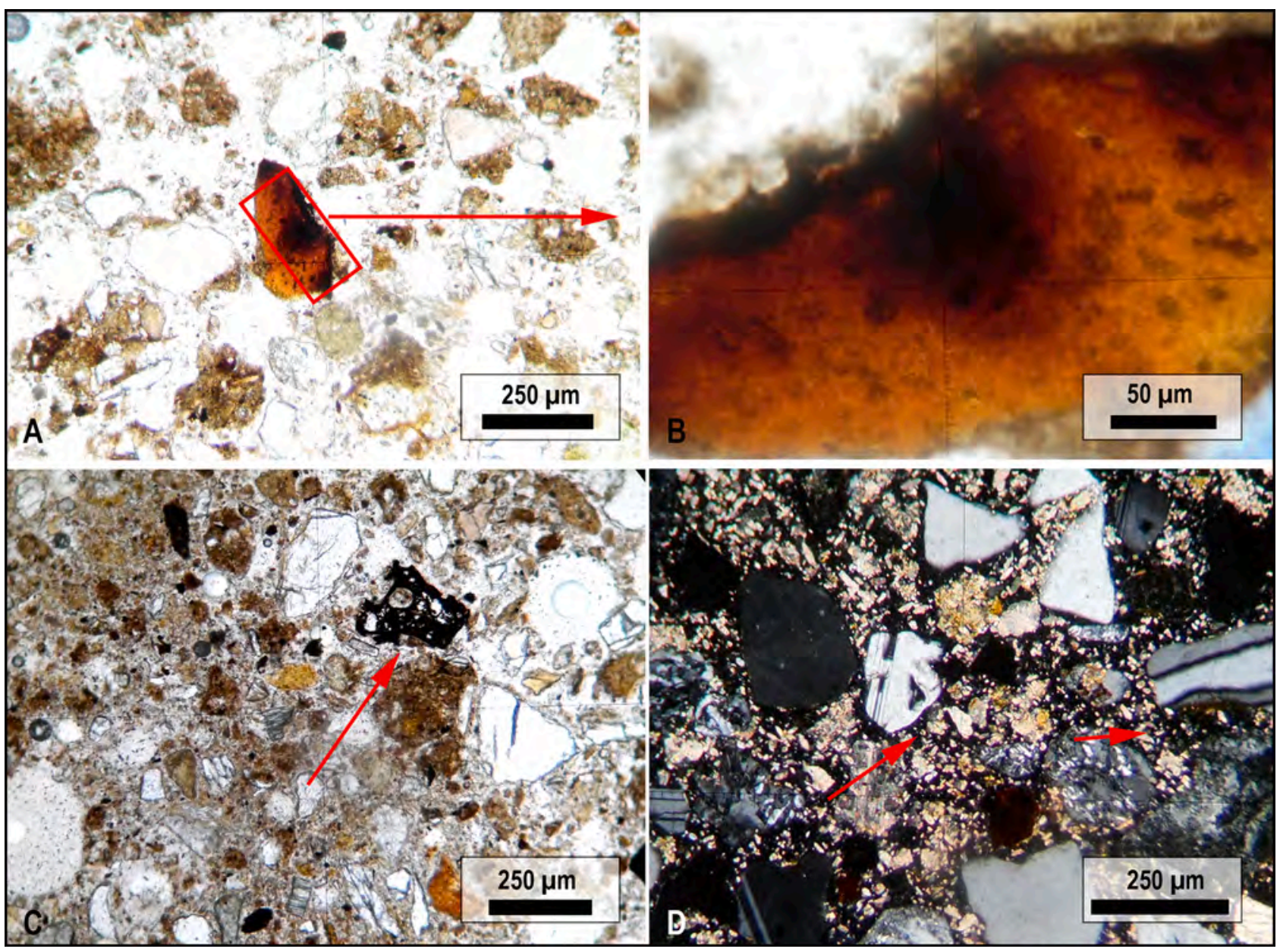

Fig. 14. Photomicrographs. A- Burnt bone fragment (sample \#21, plane polarized light). B- Same as A, with higher magnification. C- Subangular fragment of charcoal (sample \#21, plane polarize light). D- Microcrystalline calcium carbonate aggregates, whose preservation is favored under arid conditions (Canti, 2003; Gur-Arieh et al., 2014), between sand grains of quartz, plagioclase, K-feldspars and lithics (sample \#20, cross polarized light).

sense, greyish sediments observed at SJ3 (Fig. 3B) could correspond to low-temperature combustion and/ or short-duration heating processes (March et al., 2014; Kreimerman and Shahack-Gross, 2019).

The $\mathrm{X}$ of experimental samples decreases with temperature due to oxidation processes (Figs. 9A, 11), while raw samples \#21, \#20 and \#32 shows relative low $\mathrm{X}$ values (Fig. 5). This fact suggest that: 1 ) samples \#21, \#20 and \#32 suffered a thermoalteration processes and 2) such combustion occurred under oxidizing conditions, given their low organic matter content. The relatively high Hc of those samples support the latter interpretation.

The $\% \mathrm{X}_{\text {para }}$ along with the high-field upper slope branch of hysteresis loops of experimental samples broadly suggests an increase of paramagnetism with temperature (Fig. 9B). Notably, raw samples \#17, \#20, \#21 and \#32 indicate a relatively high signal of paramagnetics (Figs. 5 and 6). Such paramagnetic enhancement could partially respond to some degree of past thermoalteration processes. Nevertheless, since $\# 20$, \#21 and \#32 are related to adobe, with high clay contents, the $\%$ $\mathrm{X}_{\mathrm{para}}$ cannot be stand as a decisive indicator of thermoalteration. Alternatively, similarities between \#20, \#21 and \#32, and \#17 may rather suggest that adobe could be employed to build the small fort (\#17).

By considering all data, fire evidences are circumscribed to the adobe-wall foundation (SJ3), as expected (Section 1.3.). Indeed, adobestructural features with relatively high organic matter content (Forget et al., 2015), could have been more likely to be magnetically modified. Moreover, historical sources describe that the 1810 AD fire particularly affected armory sectors (Aragón, 1810), storage for gunpowder and ammunition. In this regard, the higher thermoalteration signal of the adobe structure (\#20, \#21) could hint that this area corresponded to the gunpowder storage of the Fuerte San José.

Certain degree of magnetic-mineral modification related to combustion at the small fort (SJ2) were also expected (Section 1.3.) as this sector probably contained a palisade (i.e., abundant fuel) and a perimeter ditch which could have behaved as a natural trap for sediments (Fig. 3B). However, present results do not follow such expectations. This fact could either signify that wind deflation favored by the topographic position of the small fort (i.e., high-exposition) rapidly removed burnt sediments and/ or there were not exist the extra-fuel availability in this sector (i.e., palisade), considering the precariousness architecture of the Fuerte San José. On the other hand, the lack of thermoaltered signals in the rest of the locality could rather respond to a low-magnitude fire unable to leave a durable soil signal, in agreement with the proposed expectation (Section 1.3).

In sum, whereas more analyses are required to further discuss the adobe sample (\#32) results, sediments from the adobe-wall foundation (SJ3) present several magnetic signals of thermoalteration, suggesting temperatures under $400{ }^{\circ} \mathrm{C}$, likely related to the documented fire. The fact that other sectors of the Fuerte San José (SJ1, SJ2, SJ4, SJ5) did not show signals of thermoalteration may suggest that the ignition source of the fire and/ or the available surface fuel were insufficient to cause a durable magnetic signature. Thus, the massive fire of the Fuerte San José described by historians (e.g., Fontana, 1873; Biedma, 1905; Barba Ruiz, 2000; Lanöel et al. 1974) is not consistent with neither the archaeological record (Bianchi Villelli et al., 2019), nor the thermoalteration signatures registered by magnetic analyses. 


\section{Conclusion}

The magnetic analysis of 32 sediment samples from the Fuerte San José, plus 40 experimental local samples heated at different temperatures was carried out in order to assessing past thermoalteration processes. The presence of superparamagnetic grains, thermo-magnetic susceptibility, the relative amount of total and paramagnetic susceptibility and the coercivity and coercivity of remanence magnetic proved to be sensible approaches to discuss the occurrence of a historical fire, particularly in a context where archaeological evidences are absent or ambiguous. Results indicate a low-magnitude fire, only registered in sediments from an adobe-wall foundation, maybe amplified by the relatively more organic matter content contained in the adobe-walls, or in the wood and thatch roofs, and/ or possibly, gunpowder. This research thus indicates that neither magnetic nor archaeological evidence supports historical narratives which describe a massive fire of the Fuerte San José in 1810 CE.

Since magnetic properties are often the outcome of several environmental processes, only the combination of many lines of evidence can improve interpretations. At this regard, the experimental design was particularly fruitful for the research process, since basic conceptual assumptions are often insufficient to explain magnetic behaviors of natural contexts. For instance, the fact that SP grains formation under oxidizing conditions already occur at $220^{\circ} \mathrm{C}$ in only one hour and reversibility of thermo-magnetic curves is outlined about $400{ }^{\circ} \mathrm{C}$, were key insights from the experiment. The methodology proposed here also allowed the formulation of stimulating questions for future agendas, such as the role of carbonates -instead of organic matter- to generate reducing conditions when heated, and how paramagnetic changes with temperature can be related to Fe-carbonate formation. Anthropogenic or natural paleo-fires analyses in arid/ semi-arid environments could be approached by the proposed methodology.

\section{Acknowledgments}

This work was funded by the project PICT-0759, Consejo Nacional de Investigaciones Científicas y Técnicas, Argentina. We thank F. Bovier, former Manager of the Administration of Natural Protected Areas of Peninsula Valdés, and the Department of Geology (UBA). We acknowledge Sebastián Oriolo for his comments on the manuscript and Magdalena Gallo for helping in laboratory tasks. Relevant bibliography suggested by Natacha Hugón, Gabriel Cocco, Ana Igareta and Ulises Camino has helped to improve key issues of this research. Finally, the authors thanks to the Editorial Board and the two reviewers for their comments.

\section{Appendix A. Supplementary data}

Supplementary data to this article can be found online at https://doi. org/10.1016/j.jasrep.2020.102577.

\section{References}

Aragón, A., 1810. Carta al Comandante del Fuerte Nuestra Señora del Carmen, 5 de septiembre, Sala X, legajo 2-3-5. Archivo General de la Nación, Buenos Aires.

Arihan, O., Güvenç, A., 2011. Studies on the anatomical structure of stems of willow (Salix L.) species (Salicaceae) growing in Ankara province, Turkey. Turk. J. Bot. 35 (6), 535-551.

Baldi, R., Cheli, G., Sauthier, D.E., Gatto, A., Pazos, G.E., Avila, L.J., 2017. Animal diversity, distribution and conservation. In: Bouza, P., Bilmes, A. (Eds.), Late Cenozoic of Península Valdés, Patagonia, Argentina. Springer, Cham, pp. 263-303.

Barba Ruiz, L., 2000. Acontecimientos históricos de Península Valdés. Comisión ProMonumentos a las gestas y primeras colonizaciones españolas del Chubut, Rawson.

Barrón, V., Torrent, J., 2002. Evidence for a simple pathway to ma-ghemite in Earth and Mars soils. Geochim Cosmochim Acta 66, 2801-2806.

Berna, F., Behar, A., Shahack-Gross, R., Berg, J., Boaretto, E., Gilboa, A., et al., 2007. Sediments exposed to high temperatures: reconstructing pyrotechnological processes in Late Bronze and Iron Age Strata at Tel Dor (Israel). J. Archaeol. Sci. 34 (3), 358-373.
Berna, F., Goldberg, P., Horwitz, L.K., Brink, J., Holt, S., Bamford, M., et al., 2012. Microstratigraphic evidence of in situ fire in the Acheulean strata of Wonderwerk Cave, Northern Cape province, South Africa. Proc. Natl. Acad. Sci. 109 (20), 1215-1220.

Bianchi Villelli, M., 2017. Colonialismo en Península Valdés: entre los proyectos defensivos y las tentativas comerciales (Patagonia norte, fines del siglo XVIII) Memoria Americana. Cuadernos de Etnohist. 25 (1), 47-75.

Bianchi Villelli, M., Buscaglia, S., Calandrón, P.D., Sellanes, A.G., 2019. Entre cerros y cañadones. Avances sobre el plano arqueológico del sitio Fuerte San José (Península Valdés, Chubut). Arqueología 25 (1), 141-167.

Biedma, J.J., 1905. Crónica histórica del Río Negro de Patagones 1774-1834. Editor Juan Canter, Buenos Aires.

Blanco, P.D., Hardtke, L.A., Rostagno, C.M., del Valle, H.F., Metternicht, G.I., 2017. Soil degradation in Peninsula Valdes: Causes, factors, processes, and assessment methods. In: Bouza, P., Bilmes, A. (Eds.), Late Cenozoic of Península Valdés, Patagonia, Argentina. Springer, Cham, pp. 191-213.

Bordas, G., 1793. Carta a F. Muñoz, Puerto Deseado, 2 de junio, Sala IX, legajo 16-4-9. Archivo General de la Nación. Buenos Aires.

Bouza, P., Ríos, I., Rostagno, C.M., Saín, C., 2017a. Soil-geomorphology relationships and pedogenic processes in Península Valdés. In: Bouza, P., Bilmes, A. (Eds.), Late Cenozoic of Península Valdés, Patagonia, Argentina. Springer, Cham, pp. 161-190.

Bouza, P., Bilmes, A., del Valle, H., Rostagno, C.M., 2017b. Late Cenozoic landforms and landscape evolution of Península Valdés. In: Bouza, P., Bilmes, A. (Eds.), Late Cenozoic of Península Valdés, Patagonia, Argentina. Springer, Cham, pp. 105-129.

Brodard, A., Guibert, P., Lévêque, F., Mathé, V., Carozza, L., Burens, A., 2012. Thermal characterization of ancient hearths from the cave of Les Fraux (Dordogne, France) by thermoluminescence and magnetic susceptibility measurements. Quat. Geochronol. 10, 353-358.

Buscaglia, S., 2017. Materiality and indigenous agency: limits to the colonial order (argentinean patagonia, eighteenth-nineteenth centuries). Int. J. Histor. Archaeol. 21 (3), 641-673.

Buscaglia, S., Bianchi Villelli, M., 2016. From colonial representation to materiality: spanish settlements on península valdés (Patagonian Coast, 1779-1810). Histor. Archaeol. 50 (2), 69-88.

Canti, M.G., 2003. Aspects of the chemical and microscopic characteristics of plant ashes found in archaeological soils. Catena 54 (3), 339-361.

Certini, G., 2005. Effects of fire on properties of forest soils: a review. Oecologia 143 (1), $1-10$.

Certini, G., Scalenghe, R., 2006. Soil formation on Earth and beyond: the role of additional soil-forming factors. Basic concepts and future challenges. Cambridge University Press, Cambridge, Soils, pp. 193-221.

Churchman, G.J., Gates, W.P., Theng, B.K., Yuan, G., 2006. Clays and clay minerals for pollution control. Dev. Clay Sci. 1, 625-675.

Coronato, F., Pessacg, N., del Pilar Alvarez, M., 2017. The climate of Península Valdés within a regional frame. In: Bouza, P., Bilmes, A. (Eds.), Late Cenozoic of Península Valdés, Patagonia, Argentina. Springer, Cham, pp. 85-104.

Dalan, R.A., 2008. A review of the role of magnetic susceptibility in archaeogeophysical studies in the USA: recent developments and prospects. Archaeol. Prospect. 15 (1), $1-31$.

Dankers, P. H., 1978. Magnetic properties of dispersed natural iron-oxides of known grain-size. PhD Thesis, 143. University of Utrecht, Netherlands.

De Bano, L.F., Neary, D., Folliot, P., 2005. Soil physical properties. In: Wildland fire in ecosystems; effects of fire on soils and water, Neary, D., Ryan, K., DeBano, L.F. (Eds.), pp. 29-52. Gen. Tech. Rep., vol. 4. Forest Service, Rocky Mountain Research Station, U.S.D.A. USA.

De Boer, C.B., 1999. Rock-magnetic studies on the hematite, maghemite and combustionmetamorphic rocks: the quest to understand the 'hidden attraction' of rocks, Geologica Ultraiectina no. 177-Mededelingen van de Faculteit Aardwetenschappen, Universitat Utrecht, Utrecht.

Dearing, J.A., Dann, R.J., Hay, K., Lees, J., Loveland, P., MaherO'grady, K., B., 1996. Frequency-dependent susceptibility measurements of environmental materials. Geophys. J. Int. 124 (1), 228-240.

Dunlop, D.J., 2002. Theory and application of the Day plot (Mrs/Ms versus Hcr/Hc) Theoretical curves and tests using titanomagnetite data. J. Geophys. Res. 107 (B3), 1029-2001.

Dunlop, D.J., Özdemir, Ö., 1997. Rock Magnetism. Fundamentals and Frontiers. Cambridge University Press, Cambridge, p. 573 pp..

Ellwood, B., Zilhão, J., Harrold, F., Balsam, W., Burkart, B., Long, G., et al., 1998. Identification of the Last Glacial Maximum in the Upper Paleolithic of Portugal using magnetic susceptibility measurements of Caldeirão cave sediments. Geoarchaeol. Int. J. 13 (1), 55-71.

Fassbinder, J., Stanjek, H., 1994. Magnetic properties of biogenic soil greigite (Fe3S4). Geophys. Res. Lett. 21 (22), 2349-2352.

Fontana, J.L., 1873. Despoblación de San José. Revista del Río de la Plata, Tomo VII:330336

Forget, M.C., Regev, L., Friesem, D.E., Shahack-Gross, R., 2015. Physical and mineralogical properties of experimentally heated chaff-tempered mud bricks: Implications for reconstruction of environmental factors influencing the appearance of mud bricks in archaeological conflagration events. J. Archaeolog. Sci. Rep. 2 80-93.

Friesem, D.E., Zaidner, Y., Shahack-Gross, R., 2014. Formation processes and combustion features at the lower layers of the Middle Palaeolithic open-air site of Nesher Ramla, Israel. Quat. Int. 331, 128-138.

García Guráieb, S., Tessone, A., Buscaglia, S., Crespo, C, Bianchi Villelli, M., del Papa, M., 2017. Análisis bioarqueológico de un individuo recuperado en el Fuerte San José 
(Pla. Valdés, Pcia. de Chubut, 1779-1810). Revista del Museo de Antropología 10(1): 61-76.

Gedye, S.J., Jones, R.T., Tinner, W., Ammann, B., Oldfield, F., 2000. The use of minera magnetism in the reconstruction of fire history: a case study from Lago di Origlio, Swiss Alps. Palaeogeogr. Palaeoclimatol. Palaeoecol. 164 (1-4), 101-110.

Gialanella, S., Girardi, F., Ischia, G., Lonardelli, I., Mattarelli, M., Montagna, M., 2010. On the goethite to hematite phase transformation. J. Therm. Anal. Calorim. 102, 867-873.

Goldberg, P., Miller, C., Schiegl, S., Ligouis, B., Berna, F., Conard, N.J., Wadley, L., 2009. Bedding, hearths, and site maintenance in the Middle Stone age of Sibudu cave, KwaZulu-Natal, South Africa. Archaeol. Anthropol. Sci. 1 (2), 95-122.

Gur-Arieh, S., Shahack-Gross, R., Maeir, A.M., Lehmann, G., Hitchcock, L.A., Boaretto, E., 2014. The taphonomy and preservation of wood and dung ashes found in archaeological cooking installations: case studies from Iron Age Israel. J. Archaeol. Sci. 46, 50-67.

Haller, M.J., Monti, A.J., Meister, C.M., 2001. Hoja Geológica 4363-I Península Valdés, Provincia del Chubut. Programa Nacional de Cartas Geológicas de la República Argentina, 1:250.000. Boletín $\mathrm{N}^{\circ}$ 266, pp 1-34; 1 mapa. Servicio Geológico Minero Argentino. Buenos Aires, Argentina.

Harrison, K., 2013. The application of forensic fire investigation techniques in the archaeological record. J. Archaeol. Sci. 40 (2), 955-959.

Heiri, O., Lotter, A.F., Lemcke, G., 2001. Loss on ignition as a method for estimating organic and carbonate content in sediments: reproducibility and comparability of results. J. Paleolimnol. 25 (1), 101-110.

Heller, F., Evans, M.E., 1995. Loess magnetism. Rev. Geophys. 33 (2), 211-240.

Hrouda, F., 2011. Models of frequency-dependent susceptibility of rocks and soils revisited and broadened. Geophys. J. Int. 187 (3), 1259-1269.

Hrouda, F., Müller, P., Hanák, J., 2003. Repeated progressive heating in susceptibility vs. temperature investigation: a new palaeotemperature indicator? Phys. Chem. Earth. 28 (16-19), 653-657.

Iglesias, T., Cala, V., Gonzalez, J., 1997. Mineralogical and chemical modifications in soils affected by a forest fire in the Mediterranean area. Sci. Total Environ. 204 (1) 89-96.

Jones, H.L. 1891. Península de San José. Revista Nacional, Tomo XIII: 326-335. Buenos Aires.

Jordanova, N., Petrovsky, E., Kovacheva, M., Jordanova, D., 2001. Factors determining magnetic enhancement of burnt clay from archaeological sites. J. Archaeol. Sci. 28 (11), 1137-1148.

Kapper, K., Anesin, D., Donadini, F., Angelucci, D., Cavulli, F., Pedrotti, A., Hirt, A., 2014. Linking site formation processes to magnetic properties. Rock-and archeomagnetic analysis of the combustion levels at Riparo Gaban (Italy) J. Archaeol. Sci. 41, 836-855.

Karkanas, P., Rigaud, J.P., Simek, J.F., Albert, R.M., Weiner, S., 2002. Ash bones and guano: a study of the minerals and phytoliths in the sediments of Grotte XVI, Dordogne, France. J. Archaeol. Sci. 29 (7), 721-732.

Ketterings, Q.M., Bigham, J., Laperche, V., 2000. Changes in soil mineralogy and texture caused by slash and burn fire in Sumatra, Indonesia. Soil Sci. Soc. Am. J. 64, 1108-1117.

Kreimerman, I., Shahack-Gross, R., 2019. Understanding conflagration of one-story mudbrick structures: an experimental approach. Archaeol. Anthropol. Sci. 11 (6), 2911-2928.

Lanöel, A., Barba Ruiz, L., Zapatero, J. M., Gutiérrez Neri, A. 1974. Recopilación histórica sobre el Fuerte San José. Comisión Pro-monumentos a las gestas y primeras colonizaciones españolas del Chubut, Dirección de Turismo. Chubut.

León, R.J.C., Bran, D., Collantes, M., Paruelo, J.M., Soriano, A., 1998. Grandes unidades de vegetación de la Patagonia extra andina. Ecología Austral 8, 123-141.

Liu, Q., Deng, C., Yu, Y., Torrent, J., Jackson, M., Banerjee, S., Zhu, R., 2005. Temperature dependence of magnetic susceptibility in an argon environment: implications for pedogenesis of Chinese loess/palaeosols. Geophys. J. Int. 161 (1), 102-112.

Lovley, D.R., Stolz, J.F., Nord Jr, G.L., Phillips, E.J., 1987. Anaerobic production of magnetite by a dissimilatory iron-reducing microorganism. Nature 330 (6145), 252.

Maher, B.A., 1986. Characterization of soils by mineral magnetic measurements. Phys. Earth Planet. Inter. 42, 76-92.

Maher, B.A., 2008. Holocene variability of the East Asian summer monsoon from Chinese cave records: a re-assessment. Holocene 18 (6), 861-866.

Maher, B.A., Taylor, R.M., 1988. Formation of ultrafine-grained magnetite in soils. Nature 336, 368-371.

Maher, B.A., Thompson, R., 1991. Mineral magnetic record of the Chinese loess and paleosols. Geology 19 (1), 3-6.

Maher, B.A., Possolo, A., 2013. Statistical models for use of palaeosol magnetic properties as proxies of palaeorainfall. Global Planet. Change 111, 280-287.

Mallol, C., Marlowe, F.W., Wood, B.M., Porter, C., 2007. Earth, wind, and fire: ethnoarchaeological signals of Hadza fires. J. Archaeol. Sci. 34 (12), 2035-2052.

March, R.J., Lucquin, A., Joly, D., Ferreri, J., Muhieddine, M., 2014. Processes of formation and alteration of archaeological fire structures: complexity viewed in the light of experimental approaches. J. Archaeol. Method Theory 21 (1), 1-45.

Martínez, J.A., 1782. Carta a F. Viedma, Puesto del Puerto San José, 10 de julio, Sala IX, legajo16-3-10. Archivo General de la Nación. Buenos Aires.

Morley, M., 2017. The Geoarchaeology of Crvena Stijena Site Formation Processes, Palaeoenvironments and Hominin Activity. In: Whallon, R. (Ed.), Crvena Stijena in
Cultural and Ecological Context. Montenegrin Academy of Sciences and Arts, Montenegro, pp. 82-131.

Mullins, C.E., 1971. The Magnetic Properties of the Soil and Their Applications to Archaelogical Prospecting. PhD thesis. University of Essex.

Oldfield, F., Crowther, J., 2007. Establishing fire incidence in temperate soils using magnetic measurements. Palaeogeogr. Palaeoclimatol. Palaeoecol. 249, 362-369.

Orgeira, M.J., Compagnucci, R., 2006. Correlation between paleosol-soil magnetic signal and climate. Earth Planets Space 58 (10), 1373-1380.

Orgeira, M.J., Egli, R., Compagnucci, R., 2011. A quantitative model of magnetic enhancement in loessic soils. Earth's Magnetic Interior 1, 361-397.

Ozán, I.L., French, C., Repetto, F.M., Vásquez, C.A., Luppo, T., 2015. Coastal Occupations in Tierra del Fuego, Southernmost South America: A Late Holocene Hunter-Gatherer Context at Marazzi 2. Geoarchaeology 30 (6), 465-482.

Ozán, I.L., Orgeira, M.J., Vásquez, C., Naselli, M., 2017. Magnetic alteration of soils by late holocene hunter-gatherer groups (Tierra Del Fuego, South America). Archaeometry 59 (6), 1135-1149.

Ozán, I.L., Méndez, C., Oriolo, S., Orgeira, M.J., Tripaldi, A., Vásquez, C.A., 2019. Depositional and post-depositional processes in human-modified cave contexts of west-central Patagonia (Southernmost South America). Palaeogeogr. Palaeoclimatol. Palaeoecol. 532, 109268

Pan, Y., Zhu, R., Banerjee, S.K., Gill, J., Williams, Q., 2000. Rock magnetic properties related to thermal treatment of siderite: behavior and interpretation. J. Geophys. Res. Solid Earth 105 (B1), 783-794.

Pérez, A., 1796a. Carta a J. Maestre, Puerto de San José y Fuerte de la Candelaria, 29 de enero, Sala IX, legajo 16-4-1. Archivo General de la Nación. Buenos Aires.

Pérez, A., 1796b. Carta a J. Maestre, Puerto de San José y Fuerte de la Candelaria, 2 de octubre, Sala IX, legajo 16-4-11. Archivo General de la Nación. Buenos Aires.

Petrochenko, K., Kurovsky, A., Godymchuk, A., Babenko, A., Yakimov, Y., Gusev, A., 2019. A case study of woody leaf litter vermicompost as a promising calcium fertilizer. Bulgarian J. Agric. Sci. 4 (25), 646.

Roberts, A.P., Cui, Y., Verosub, K.L., 1995. Wasp-waisted hysteresis loops: Mineral magnetic characteristics and discrimination of components in mixed magnetic systems. J. Geophys. Res. Solid Earth 100 (B9), 17909-17924.

Robin, V., Nelle, O., 2014. Contribution to the reconstruction of central European fire history, based on the soil charcoal analysis of study sites in northern and central Germany. Vegetation History and Archaeobotany 23 (1), 51-65.

Rooksby, H.P., 1961. Oxides and hydroxides of aluminium and iron. In: Brown, G. (Ed.), The X-ray Identification and Crystal Structures of Clay Minerals. Mineralogical Society, London, pp. 354-392.

Schwertmann, U., Taylor, R., 1989. Iron oxides. In: Dixon, J., Weed, S. (Eds.), Minerals in Soil Environments. Soil Science Society of America Books Series, Second edition, Madison, pp. 379-465.

Shahack-Gross, R., 2018. Fire and Society in the Eastern Mediterranean. A Diachronic View with a Microarchaeological Focus. In: Yasur-Landau, A., Cline, E.H., Rowan, Y. (Eds.), The Social Archaeology of the Levant: From Prehistory to the Present. Cambridge University Press, Cambridge, pp. 86-97.

Shahack-Gross, R., Shaar, R., Hassul, E., Ebert, Y., Forget, M., Nowaczyk, N., Shmuel, M., Finkelstein, I., Agnon, A., 2018. Fire and collapse: untangling the formation of destruction layers using archaeomagnetism. Geoarchaeology 33 (5), 513-528.

Soler, M., García, P., 1779. Informe de Manuel Soler y Pedro García. Fuerte San José, octubre 1779. Audiencia de Buenos Aires, 326. Folios 1039-1050. Archivo General de Indias. Sevilla.

Tauxe, L., Mullender, T.A., Pick, T., 1996. Potbellies, wasp-waists, and superparamagnetism in magnetic hysteresis. J. Geophys. Res. Solid Earth 101 (B1), 571-583.

Taylor, R.M., Schwertmann, U., 1974. Maghemite in soils and its origin: I. Properties and observations on soil maghemites. Clay Miner. 10 (4), 289-298.

Tello, F.J., Sanz Sanz, M.V., 1994. Estética y teoría de la arquitectura en los tratados españoles del siglo XVIII. Consejo Superior de Investigaciones Científicas, Madrid.

Théry-Parisot, I., Chabal, L., Chrzavzez, J. 2010. Anthracology and taphonomy, from wood gathering to charcoal analysis. A review of the taphonomic processes modifying charcoal assemblages, in archaeological contexts. Palaeogeography, palaeoclimatology, palaeoecology 291(1-2):142-153.

Tite, M.S., Mullins, C., 1971. Enhancement of magnetic susceptibility of soils on archaeological sites. Archaeometry 13, 209-219.

Torrent, J., Barrón, V., Liu, Q., 2006. Magnetic enhancement is linked to and precedes hematite formation in aerobic soil. Geophys. Res. Lett. 33 (2), 1-4.

Ulery, A.L., Graham, R., Bowen, L., 1996. Forest fire effects on soil phyllosilicates in California. Soil Sci. Soc. Am. J. 60 (1), 309-315.

Urban, T.M., Rasic, J.T., Alix, C., Anderson, D.D., Chisholm, L., Jacob, R., et al., 2019. Magnetic detection of archaeological hearths in Alaska: a tool for investigating the full span of human presence at the gateway to North America. Quat. Sci. Rev. 211, 73-92.

Vásquez, C.A., Orgeira, M.J., Sinito, A.M., 2009. Origin of superparamagnetic particles in Argiudolls developed on loess, Buenos Aires (Argentina). Environ. Geol. 56 (8), $1653-1661$.

Vásquez, C.A., Sapienza, F.F., Somacal, A., Fazzito, S., 2018. Anhysteretic remanent magnetization: model of grain size distribution of spherical magnetite grains. Stud. Geophys. Geod. 62 (2), 339-351.

Vega, P., Juan, A., Guerra, M.I., Morán, J.M., Aguado, P.J., Llamas, B., 2011. Mechanical characterisation of traditional adobes from the north of Spain. Constr. Build. Mater. 25, 3020-3023. 
Viedma, A., 1779. Carta al Virrey J. J. Vértiz, Buenos Aires, 25 de agosto, Sala IX, Legajo 23-10-3. Archivo General de la Nación. Buenos Aires.

Villagran, X., Strauss, A., Miller, C., Ligouis, B., Oliveira, R., 2017. Buried in ashes: Site formation processes at Lapa do Santo rockshelter, east-central Brazil. J. Archaeol. Sci. $77,10-34$.
Whitlock, C., Larsen, C., 2002. Charcoal as a fire proxy. In: Smol, J.P., Birks, H.J., Last, W.M. (Eds.), Tracking environmental change using lake sediments. Springer, Dordrecht, pp. 75-97.

Worm, H.U., 1998. On the superparamagnetic-stable single domain transition for magnetite, and frequency dependence of susceptibility. Geophys. J. Int. 133, 201-206. 